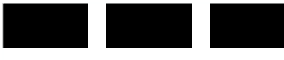 \\ DE \\ THE WiLliam DAVIDSON INSTITUTE \\ AT THE UNIVERSITY OF MICHIGAN
}

\section{Foreign Direct Investment and Structural Reforms:} Evidence from Eastern Europe and Latin America

\author{
By: Nauro Campos \& Yuko Kinoshita
}

William Davidson Institute Working Paper Number 906

January 2008 


\title{
Foreign Direct Investment and Structural Reforms: Evidence from Eastern Europe and Latin America*
}

\author{
Nauro Campos \\ Brunel University, IZA and CEPR \\ Nauro.Campos@brunel.ac.uk
}

\author{
Yuko Kinoshita \\ International Monetary Fund \\ ykinoshita@imf.org
}

January 2008

\begin{abstract}
This paper investigates the role of structural reforms privatization, financial reform and trade liberalization- as determinants of FDI inflows based on newly constructed dataset on structural reforms for 19 Latin American and 25 Eastern European countries between 1989 and 2004. Our main finding is a strong empirical relationship from reforms to FDI, in particular, from financial liberalization and privatization. These results are robust to different measures of reforms, split samples, and potential endogeneity and omitted variables biases.
\end{abstract}

JEL Classification Numbers: H11, F21, O16

Keywords: privatization, financial reform, trade liberalization, foreign direct investment, Latin America, transition economies

* We are grateful to Enrica Detragiache, John Earle, Saul Estrin, Rolf Langhammer, Branko Milanovic, Elias Papaioannou, Koen Schoors, Gabriele Tondl and seminar participants at the IMF, ASSA (New Orleans) and at the ELSNIT Conference (Barcelona) for valuable comments on earlier versions. We also thank Sunita Kikeri and Marcelo Oleorraga from The World Bank for assistance with data on privatization and trade, respectively. Mark Parrett provided superb research assistance. The views expressed in this paper are those of the authors alone and do not necessarily represent those of the IMF or IMF policy. The authors alone are responsible for any remaining errors. 


\section{INTRODUCTION}

Foreign direct investment (henceforth FDI) is an important component of capital flows in financial globalization. Though the vast literature lacks consensus on the benefits of financial globalization, FDI is believed to be one of the most important channels through which financial globalization benefits the economy (Prasad and others, 2003). Various studies find evidence in support of the benefits of a positive effect on growth via technology spillovers. FDI is also the least volatile form of capital flows, making countries less vulnerable to sudden stops or reversals of flows (Kose and others, 2006). Against this background, many countries consider attracting FDI as an important element for economic development. Thus, an important policy question is what are the factors that attract FDI.

This paper attempts to answer the question with a special focus on the role of structural reforms. We construct a unique panel data set for 19 Latin American countries (LACs) and 25 transition economies (TEs) from 1989 to 2004. ${ }^{1}$ Both regions-Latin America and transition economies - undertook massive structural reforms since the early 1990s. In many countries in both regions, financial markets were liberalized, trade barriers had been greatly reduced, and state-owned enterprises were privatized to a large extent. From a point of view of foreign investors, investment decisions in emerging markets are influenced by economic and political risks.

Many believe that successful implementation of structural reforms by the host government is a positive signal to foreign investors as it implies less investment risk. Thus,

\footnotetext{
1 There are numerous papers examining FDI inflows in Latin American and in transition economies, separately. For Latin American countries see, among others, De Gregorio (1992), Trevino et al. (2002), and Bengoa and Sanchez-Robles (2003). For transition economies, see among others, Bevan and Estrin (2000), Garibaldi at al (2001), and Resmini (2000).
} 
the progress of structural reforms can be an impetus to strong foreign investment flows. We also argue that structural reforms go beyond being just a signal. They generate real benefits to foreign investors by affecting the key parameters upon which the decision to invest in a foreign country is taken.

Despite its relevance, there exists little empirical study relating FDI flows and structural reforms. One of the main reasons for this is a paucity of the data comparable across countries and regions on structural reforms. ${ }^{2}$ One main contribution of this paper is the construction of various structural reform indicators that are comparable across countries in more than one region and consistently defined over time. ${ }^{3}$

Another important reason for the relative paucity of research on this topic is the common misconception that the relation between FDI and structural reforms is axiomatic. In other words, one might argue "FDI is reform;” e.g., less restrictions to foreign capital imply more FDI inflows, and more privatization means more foreign investors are interested in entering domestic market through acquisition. This argument runs into trouble once we recall that structural reforms come in different shapes and forms. That is, the same reform in different countries may have opposite effects due to institutional differences. Also, a set of reforms may also have different joint effects because of their substitutability or complementarity, or because of sequencing issues. ${ }^{4}$

In constructing the data, we also try to isolate reform efforts from reform outcomes.

\footnotetext{
${ }^{2}$ The existing studies on structural reform are mostly limited to industrial countries owing to data availability (e.g., Chapter III, WEO, April 2004).The notable exceptions are Abed and Davoodi (2000) and Lora (1998) for transition economies and Latin America countries, respectively.

${ }^{3}$ The structural reform variables consist of the following three components: financial sector liberalization, trade liberalization, and privatization. See Section IV for the definitions of the variables in detail.

${ }^{4}$ Dewatripont and Roland (1995) find that gradualist reform strategies as opposed to big-bang strategies may be more effective in attracting welfare-enhancing foreign investment in the presence of uncertainty.
} 
Namely, regarding financial liberalization, we differentiate a set of measures that range from indicators of financial development (outcomes) to measures closer to the policy changes (efforts) of the government in this regard. ${ }^{5}$

Using this newly constructed data, our principal finding from regression analyses is that of a strong relationship from structural reforms to FDI. Among the structural reforms considered in the study, we find a stronger effect on FDI from financial sector reforms than privatization and trade liberalization, suggesting that foreign investors do value highly a host country's financial system that is able to allocate capital efficiently, monitor firms, ameliorate, diversify and share risk, and ultimately mobilize savings. These results give rise to a "paradox of finance:" why do multinational firms that are not clearly financially constrained systematically invest in countries in which such constraints are most relaxed? Our explanation is that financial development may be a precondition to the maximization of the benefits of spillovers via the backward linkages to foreign investors.

It should be also noted that our finding on the relative importance of financial reforms on FDI additional support to the existing literature. For example, Alfaro and others (2004) examine the links among FDI, financial development, and economic growth and find that countries with better developed financial markets are able to exploit FDI more efficiently. They argue "the potential of FDI to create backward linkages in the absence of welldeveloped financial markets is severely impeded” (Alfaro and others (2004), p. 92). Similarly, Prasad and others (2007) also argue that the absorptive capacity measured by financial development of the recipient country is a precondition to the benefits of foreign capital inflows to higher growth.

\footnotetext{
${ }^{5}$ The analogy for trade liberalization is as follows: trade openness is a measure of reform outcome, while actual tariffs and their dispersion are a better measure of government reform efforts.
} 
Our results support and extend those findings by suggesting that financial reform is not only more important than financial development but also financial reform is more important than other structural reforms.

In addition to financial and privatization reforms, foreign investors are attracted to countries with more stable macroeconomic environment, higher levels of economic development, and infrastructure. We find that these results are robust to different measures of FDI, reform, different estimators, split samples, measurement error, endogeneity, and potential omitted variables bias.

An important recent development in the literature is the incorporation of institutional quality in the modeling of the FDI location determinants. We also control for various aspects of institutional quality. Our regression results hold up well after the inclusion of institutional variables, which is in line with those put forward by Alfaro and others (2004), Bevan and others (2004), and Gastanaga and others (1998). ${ }^{6}$

The paper is organized as follows. Section II reviews a recent development in the two regions during the period. Section III describes in detail the construction of the structural reform variables used to examine the determinants of FDI. Section IV discusses the underlying theoretical framework on the determinants of FDI inflows in relation to the rest of the empirical literature. Section V reports our main econometric results and sensitivity checks. Section VI concludes the paper and outlines directions for future research.

\footnotetext{
${ }^{6}$ Alfaro et al. (2004) present cross-sectional (long-term) results, while Bevan et al. (2004) focus only on the transition economies. Our paper differs from Gastanaga et al. (1998) in that we look at fewer reforms in fewer regions (although our samples are of approximately the same size) but we use measures of reform that try to separate reform inputs to reform outcomes and examine the effects of reform controlling for a richer set of standard determinants. It is also noteworthy that Gastanaga et al. (1998) argue that panel results on the relationship between reform and FDI tend to differ significantly from those from pure cross-section analysis. We also find support for this notion in the sense that the results for our institutional measures tend to be much stronger in the cross-section than in the panel.
} 


\section{FDI IN TRANSITION ECONOMIES AND LATIN AMERICA}

This section gives a brief overview of recent developments in the two regions (TEs and LACs) during the period 1989-2004.

The transition from centrally planned to market economy started more or less simultaneously in nearly thirty countries with similar inherited institutions, initial conditions, and income levels. A number of centrally planned economies set out to implement economic and political reforms, choosing different strategies and ending up experiencing dramatically different outcomes in many areas, including FDI flows. The period of our analysis for Latin America corresponds roughly to the one Krueger calls "a decade of disappointment." ${ }^{7}$ We think that this term also works well to describe the transition experience given that the latter is marked by an unexpectedly severe fall of per capita GDP.

The collapse of the socialist and import-substitution systems somewhat coincided and provided myriad investment opportunities. Many of these economies were industrialized and could count on a relatively cheap yet educated workforce. FDI was perceived as an important catalyst for technological advancement necessary for making them competitive in the international market. Yet these high hopes for FDI contrast sharply with the reduced role governments in transition economies allowed for foreign investors during the privatization process (Hungary is an exception) as well as against the backdrop of disappointingly large falls in output per capita and of extended recessions (Campos and Coricelli, 2002). It can be seen in Figures 1 and 2 that TEs had received less FDI than LACs throughout the 1990s, reversing the trend only after 2002.

7 See 'Forward' in Singh and others (2005). 
The 1990s in Latin America were a decade of intense structural reform as well (Singh et al. 2005). The first years of the decade saw the implementation of various major macroeconomic stabilization programs that were successful after much trial and error, with the notable exception of Brazil where stabilization succeeded only in 1994 with Plano Real.

Macroeconomic stability paved the way for the adoption, implementation, and deepening of important structural reforms. Aggressive programs of trade liberalization (e.g., Chile) were implemented, privatization programs were adopted, and the liberalization of labor and credit markets were pursued with different degrees of success across the region. The period is said to be disappointing because, although reforms were implemented in Latin America with more intensity than in most developing countries, the growth pay-offs turned out to be low and came accompanied by unexpected and severe financial crises (Singh, 2006). ${ }^{8}$

As far as FDI inflows are concerned, early hopes have not thus far materialized. FDI inflows into LACs are larger than those of TEs during the 1990s (Figures 1 and 2) but they had come to a halt at the time of the Asian crisis.

According to UNCTAD, LACs received about 10 percent of global FDI inflows between 1990 and 1994 while Asia received almost twice as much. In the second half of the 1990s, the share of FDI into LACs had increased to about 12 per cent but it still falls far short of Asia, which accounts for 16 percent. Also, FDI inflows were disproportionately concentrated in a handful of countries such as Argentina, Brazil, Chile, and Mexico.

\footnotetext{
${ }^{8}$ Lora and others (2003) talk of "reform fatigue" as the region sees the disappointing effect of the reforms on growth after extensive pro-market reforms in the 1990s. For example, average yearly per capita GDP growth rate was only 2.1 percent in the 1990s compared with more than 3 percent for the 1960s and 1970s.
} 


\section{MODELING THE DETERMINANTS OF FDI}

\section{A. Brief overview of the literature}

The considerable theoretical work on the determinants of FDI identifies ownership advantages, location advantages, and benefits of internalization as the main elements (Dunnings, 1974; Hymer, 1960; Caves, 1982). Past studies can be classified largely into two groups. One group focuses on an analysis of the determinants endogenous to the multinational investing firms such as the size of the firm and R\&D intensity, and asks why a firm becomes a foreign investor. The other group examines factors exogenous to the investors, namely, such location advantages of the host country as market size and labor cost. ${ }^{9}$ In the rest of the section we focus on the latter group as this paper examines the determinants of FDI that are exogenous to the investor but endogenous to the host country.

What are the factors that attract FDI? The literature indicates that the key locational determinants are the classical sources of comparative advantages of the host country. Firms choose the investment site that minimizes the cost of production. ${ }^{10}$ Notably, host country market size and relative factor prices (i.e., natural resources, labor cost, and human capital) all affect the expected profitability of foreign investment (Kravis and Lipsey, 1982).Wheeler and Mody (1992) find that infrastructure availability is particularly an important domestic country attribute for foreign investors in the U.S. Also, they find the past stock of foreign investment also important in explaining FDI inflows. The riskiness of investment in terms of economic and political environment also affects the expected return to the investment. In this respect, greater macroeconomic and political stability of the host country could attract more foreign investment (Bevan and Estrin, 2000). It is also argued that FDI and trade openness can be

\footnotetext{
${ }^{9}$ See Blonigen (2005) for a survey of the literature on FDI determinants.

${ }^{10}$ Wheeler and Mody (1992) provide a comprehensive summary of the classical sources of comparative advantages.
} 
positively related as FDI flows can be considered complementary to trade flows (Caves, 1992; Singh and Jun, 1996).

A number of recent works examine FDI to the TEs. Resmini (2000) and Bevan and Estrin (2000) examine the drivers for FDI into 11 transition countries in the pooled and panel settings, respectively. They put forward the notion that the prospect of European Union membership played an important role in attracting export-platform FDI. Campos and Kinoshita (2003) also examine FDI determinants, expanding the set of host countries to 25 transition countries in a Generalized Method of Moments (GMM) framework and stressing the importance of institutions and natural resource abundance in foreign investors' locational decision. More recently, Demekas and others (2005) try to explain FDI flows into Southeastern European countries by using the gravity equation. Garibaldi and others (2001) have also produced an important paper on FDI in TEs in which they examine the overall level as well as the composition of private capital flows. They find that FDI allocation across countries is well explained in terms of macroeconomic and initial condition variables. The work on the determinants of FDI in Latin American countries is also vast. De Gregorio (1992) examines the impact of FDI on long-term growth in a large number of Latin American countries and finds that FDI is three to six times more efficient than total investment (1992, 93). Bengoa and Sanchez-Robles (2003) find that the overall level of economic freedom, economic stability and the level of human capital are important determinant of FDI for subset of Latin American countries. More closely related to our study, Trevino and others (2002) examine the effects of three types of reforms-microeconomic, macroeconomic and institutional—on FDI inflows in seven Latin American countries between 1998 and 1999. They report that the most significant factors explaining FDI inflows are the level of GDP, privatization, and CPI inflation proxying macroeconomic stabilization. 


\section{B. Econometric model}

This study draws on the existing literature on the determinants of cross-country FDI.

Specifically, we test for three categories of the determinants. First, we look into traditional or classical factors such as market size, infrastructure, and macroeconomic environment. Second, we look at institutional factors. Third, we question whether the host country government’s structural reforms play a significant role in attracting foreign investors, especially in emerging economies.

In our baseline model, we specify FDI as a function of three main groups of variables: a set of classical determinants of FDI, structural reforms, and institutional quality. The baseline econometric model is as follows:

$$
\begin{aligned}
& Y_{i t}=\lambda X_{i t}+\varepsilon_{i t} \\
& \varepsilon_{i t}=\eta_{i}+\gamma_{t}+u_{i t},
\end{aligned}
$$

where $Y_{i t}$ is the dependent variable which is measured as FDI as a ratio of GDP in country $i$ at year $t .{ }^{11} \mathrm{X}_{i t}$ includes (i) the classical factors (market size, initial income level, natural resource abundance, infrastructure, inflation), (ii) structural reform variables (overall financial market development, bank efficiency, trade liberalization, privatization), and (iii) institutional variables (quality of bureaucracy, executive constraints, rule of law). ${ }^{12}$ In addition, $\eta_{i}$ represents unobservable country-specific attributes and $\gamma_{t}$ is a vector of time-specific effects (e.g., time dummies).

\footnotetext{
${ }^{11}$ Alternatively, we use the log of FDI per worker. The main reason for using FDI per worker is that, in developing countries, large informal sectors are not uncommon and they affect the official GDP figures.

${ }^{12}$ More details on the variables are found in the next section.
} 
It is a well-known concern in the literature that some of the regressors may be potentially endogenous or predetermined in determining FDI flows. For example, FDI might be attracted to a country that has a more liberalized financial market but at the same time financial liberalization may be enhanced by the presence of FDI. If we were to run the ordinary least squares (OLS) regression on (1), the estimate would be biased as the error term is correlated with Xs.

To address the potential endogeneity of regressors and to incorporate fixed effects, we employ the system-GMM estimator from Blundell and Bond (1998). The Blundell-Bond estimator is arguably a superior approach to the Arellano-Bond difference-GMM as adding lagged differenced variables as instruments in the level equations may generate substantial efficiency gains when the time window is relatively short. ${ }^{13}$ Another advantage of the systemGMM estimation is its ability to identify the coefficients of time-invariant variables in the level equation.

System GMM also has advantages over the standard or difference IV estimates because as the length of the panel increases, so does the number of valid instruments. For equation (1), valid instruments are lagged levels of dependent variables, $Y_{i t-s}$ where $s \geq 2$ and $t=3,4, \ldots, T$. If $X_{i t}$ is strictly exogenous, then $\Delta X_{i t-s}$ (for all s) can be used as additional instruments to increase the efficiency of the estimates. The validity of instruments is checked by the Sargan test. The second-order correlation of the error term in the first-differenced equation is assessed using Arellano-Bond statistics for autocorrelation, which is asymptotically distributed as $\mathrm{N}(0,1)$. When the number of observations is small relative to

\footnotetext{
${ }^{13}$ The difference-GMM estimator utilizes lagged levels as instruments in the difference equations (Arellano and bond, 1991), whereas the system-GMM estimator uses lagged differences as additional instruments in the level equations.
} 
parameter estimates, we should be attentive to the possibility of small sample bias in the GMM estimation.

The main reasons for foreign investors to choose a certain investment location can be explained by several motives such as market-seeking and resource-seeking (Lipsey, 2006). If FDI is market-seeking, then a large host country's market size and high growth prospects can be the main drivers of FDI. If it is resource-seeking, FDI is drawn to the location endowed with abundant natural resources. To test for these different hypotheses, we include various classical determinants of FDI as the first set of explanatory variables.

In order to test for these different hypotheses, we include various classical determinants of FDI as the first set of explanatory variables. Namely, we measure market size by log of GDP. If investment decisions are of market-seeking nature (i.e., sell in the local market), then we would expect this to be positive. Natural resources endowment may also be an important factor, particularly for resource-driven FDI. We use (log of) the percentage of fuel and natural gas in total exports as a proxy for natural resource dependence. Log GDP per capita captures the level of development across countries, which reflects among other things differences in initial conditions. Inflation is a standard proxy for macroeconomic stability. We expect a negative sign on the coefficient of (log) inflation as low inflation is perceived by foreign investors as a favorable signal and it should lead to more FDI. Sufficient infrastructure is another factor that allures foreign investors to a country. We use (log of) the number of main telephone lines as our infrastructure variable. Availability of main telephone lines is important to facilitate communication and help integrate the domestic market and, given that other important elements of the national infrastructure (for instance, internet services or computer usages) are often complementary to telephones lines, this variable 
provides a useful proxy for the overall quality of infrastructure in the host country. ${ }^{14}$

A second set of explanatory variables includes those that are related to structural reforms: financial reform, trade liberalization, and privatization efforts. Recent literature of capital account liberalization argues that pre-commitment to structural reforms can encourage more stable and longer-term capital inflows to the host country (Forbes, 2006). In our view, these three are among the most important reforms that help bring in FDI to the host country.

A third set of variables include various measures of institutional quality. A growing body of literature in economic growth emphasizes the role of good economic institutions in promoting higher investment, higher educational attainment, and lower mortality. In the context of FDI, institutions underpin local business operating conditions, but they differ from “physical” supporting factors such as transport and communication infrastructure. Consider, for instance, the context in which a fair, predictable, and expedient judiciary, an efficient bureaucracy and less corruption may help attract FDI. On the other hand, as the recent literature of international trade argues, institutional quality matters to the firm's decision to choose FDI as a mode of entry as opposed to outsourcing because of the hold-up problem (Antras, 2003). ${ }^{15}$ If this is indeed the case, poor institutional quality would encourage more FDI, ceteris paribus. Thus, the theories point to two possibilities regarding the role of institutions in affecting FDI inflows. Good institutions may increase or decrease FDI inflows depending on the sector and type of FDI the country receives. In the past, data limitations have impeded extensive testing of these ideas, constraining them to focus on just one aspect of the issue, normally corruption. In this paper, we examine an array of institutional features

\footnotetext{
${ }^{14}$ For discussions of other infrastructure variables, see below.

${ }^{15}$ The hold-up problem arises when the firms' necessary investments are relationship-specific and it is impossible ex-ante to write complete contracts covering all contingencies between the buyer and seller. In the absence of property right protection, a firm would prefer to engage in vertical integration rather than the arm's length contracts with outside suppliers.
} 
and try to assess their relative importance. The institutional quality variables used in this study are the rule of law, quality of bureaucracy, and executive constraints.

\section{DATA AND MEASUREMENT: FDI, STRUCTURAL REFORMS AND INSTITUTIONS}

In this section, we describe the data set we put together for this paper. Our data set covers 19 Latin American and 25 transition economies from 1989 to $2004 .{ }^{16}$ We describe the FDI measures, the indexes of financial reform, and of trade liberalization, the privatization index, and the various institutional measures (executive constraints, corruption, rule of law and quality of the bureaucracy), as well as the additional controlling variables (such as natural resources, infrastructure, and market size).

\section{A. Foreign Direct Investment}

The data on foreign direct investment are from International Financial Statistics (IFS). These are balance of payments data reflecting capital inflows to acquire a lasting management interest in an enterpise operating in a different economy than that of the investor (where lasting interest is defined in standard fashion as acquiring at least 10 percent of total ownership).

Figures 1 and 2 show FDI inflows over GDP and FDI inflows per worker, respectively. First, it is interesting to note that throughout the 1990s average FDI inflows (over GDP as well as per worker) to LACs tend to be substantially larger than to transition economies, with this reversing only for two years of our whole period of analysis. For the

\footnotetext{
${ }^{16}$ The Latin American countries (LACs) are Argentina, Bolivia, Brazil, Chile, Colombia, Costa Rica, Dominican Republic, Ecuador, El Salvador, Guatemala, Honduras, Jamaica, México, Nicaragua, Paraguay, Perú, Uruguay, Venezuela, and Trinidad and Tobago; while the Transition economies (TEs) are Albania, Armenia, Azerbaijan, Belarus, Bulgaria, Croatia, Czech Republic, Estonia, Georgia, Hungary, Kazakhstan, Kyrgyz Republic, Latvia, Lithuania, Macedonia, Moldova, Poland, Romania, Russia, Slovak Republic, Slovenia, Tajikistan, Turkmenistan, Ukraine, and Uzbekistan.
} 
years up to the East Asian crisis, the behavior of the two series in the two regions is similar, both showing a rapid increase in FDI inflows. The East Asia crisis of 1997 quickly spilled over to Brazil and Russia (Kaminsky and Reinhart, 2000) but has acquired different dynamics depending on the region: Figures 1 and 2 show that, in Latin America, FDI inflows come to a halt and have yet to recover in GDP terms although they did recover in 2004 in per worker terms (Calvo, 2003), while for the transition economies these effects seem milder with FDI inflows recovering two years after the crisis. The relatively small dip in 2002 in Latin America coincides with the Argentinean Crisis.

\section{B. Measures of Structural Reform}

Investment decisions in emerging markets are often influenced by economic and political risks. Successful implementation of economic reform by the host government provides a positive signal to investors, as progress toward a stable macroeconomic environment implies less investment risk and uncertainty. Our goal is to construct measures that are comparable across regions and over time. The data requirements are high: we need yearly data for a panel of countries from two different regions on a number of reform variables that, for comparability purposes, should ideally come from the same source. ${ }^{17}$ In light of these requirements, we decided to focus on three reform areas: financial sector reform, privatization, and trade liberalization. ${ }^{18}$

\footnotetext{
${ }^{17}$ Notice this rules out a number of options, such as the European Bank for Reconstruction and Development (EBRD) and Inter-American Development Bank Annual reports.

${ }^{18}$ We started out with the following set of reforms in mind: financial sector reform, privatization, trade liberalization, tax reform, labor market reform, and changes in the regulatory framework (the latter, along the lines of the World Bank's Doing Business project). Yet, data availability forced us to focus only on these three reforms.
} 
Another important concern in constructing these reform measures is to try not to confuse reform efforts with reform outcomes. ${ }^{19}$ For instance, in discussions of trade liberalization reform efforts based upon indicators of trade openness are common. Yet improvements in trade openness can be generated by myriad of reasons other than attendant changes in trade policy (for instance, it can be driven by exchange rate movements, technological change, climate shocks, and unilateral changes in trade policy stances of major trading partners). A similar case can be made for privatization and financial reform. Consider the use of the share of private sector in GDP for the former, and the use of proxies for financial development in the latter. With this concern in mind, we put forward the notion that one of the main advantages of our reform indexes is that they explicitly try to isolate the effect of reform efforts from that of reform outcomes, and mostly capture the former. As mentioned, our overall financial reform index and our stock-market development measure are not inputonly measures of reform.

One could argue that this is not the case with respect to our index of the efficiency of financial intermediation. In order to attend this issue, we also use a more detailed set of policy reform variables drawn from Detriagiache and others (2007). By so doing, we can test if policy changes rather than possible reform outcomes affect FDI inflows.

\section{Financial sector development and reform}

We construct several indicators for financial sector reform..$^{20}$ The source of our data is the recently updated (February 2006 version) World Bank’s Financial Structure Dataset (Beck et al., 2000). ${ }^{21}$ This data set has been widely used in the financial liberalization literature as a

\footnotetext{
${ }^{19}$ Rodrik (2005) and Loayza and Soto (2004) also make this important point.

${ }^{20}$ We also constructed another measure of financial liberalization based on stock capitalization, which was not used in the regressions.

${ }^{21}$ Available at http://econ.worldbank.org/staff/tbeck
} 
main source for financial reform indicators. The first indicator reflects overall financial development and the second reflects the efficiency of the banking sector. Notice that only the second indicator corresponds to reform efforts (inputs), while the first one is better at capturing overall reform outcomes. This should help us investigate how important it actually is to try to differentiate between inputs and outcomes. ${ }^{22}$

The three underlying variables for the first financial reform index are the ratio of liquid liabilities to GDP, based on the liquid liabilities of the financial system (currency plus demand and interest-bearing liabilities of bank and non-bank financial intermediaries); the ratio to GDP of credit issued to the private sector by banks and other financial intermediaries; and the ratio of commercial bank assets to the sum of commercial bank assets and central bank assets. We generated two versions of this index: one is an arithmetic average of the normalized values (more details shown below) of these three variables, and the second is based solely on the ratio of commercial bank assets to the sum of commercial bank assets and central bank assets.

In order to normalize our reform measures into indices that reflect the strengthening of the operation of the market, we use the procedure suggested by Lora (1998), which involves subtracting each value from the series maximum and dividing this by the series range (maximum minus minimum value) which yields values between 0 and 1 scale (with 1 indicating the maximum in-sample level of reform):

\footnotetext{
${ }^{22}$ These two indexes are also helpful in distilling different interpretations of the effects of financial reform. The underdevelopment of financial markets may encourage FDI inflows in search of monopoly power, or financial market deregulations may be taken as a credible signal of a host government committed to economic reforms (e.g., multinational firms seldom depend on the host country's financial markets to raise finance). In the next section, we report that the second index is significant suggesting more weight should be given to the second explanation.
} 


$$
I_{i}=\frac{1}{m_{i}} \frac{1}{n_{i}} \sum_{j=1}^{m_{i}} \sum_{t=1}^{n_{i}}\left[\frac{\left(V_{j \max }-V_{j i t}\right)}{V_{j \max }-V_{j \min }}\right],
$$

where $V$ is a value of $j$-th variable in $i$-th country in time $t, n$ stands for the number of the years and $m$ for the number of variables. One main advantage of such transformation is that it allows our reform series to be measured over the same scale. Another advantage is that the reference point is the maximum in-sample value that changes over time (that is, it is not bound from above and does not refer to some idealized perfectly functioning market economy). Notice we apply this normalization to all of our reform indexes below.

Our second index of financial reform measures the efficiency of financial intermediation and it is built upon two variables: the ratio of overhead costs to total bank assets and the "net interest margin,” which equals the difference between bank interest income and interest expenses, divided by total assets. Because larger values of these two variables are associated with a more inefficient financial sector, we adjusted the normalization above (in the numerator we subtracts the actual value from the minimum instead), so that the resulting figures read in tandem with our other reform indicators (larger values indicating more efficient financial intermediation). ${ }^{23}$

Figures 3 and 4 show these financial reform indexes over time for the two regions. As expected, they reveal different aspects of financial reform. From Figure 3, financial reform as overall financial development was relatively more intense in the transition economies than in Latin America from 1989 to the mid-1990s, with the situation reversing after that (except for

\footnotetext{
${ }^{23}$ We also generate a third index of financial reform measuring of the level of stock-market based financial development (as opposed to the more traditional, bank-based indicator described above). This index was constructed upon three variables: (a) the ratio of stock market capitalization to GDP, (b) the total value traded: the ratio of trades in domestic shares (on domestic exchanges) to GDP, and (c) the turnover ratio, which is the ratio of trades in domestic shares to market capitalization. As the results turn out to be similar to the ones for the first financial development index, we refrain from reporting them for the sake of space.
} 
the post 2001 years). Regarding our indicator of the efficiency of the financial sector, Figure 4 shows that the transition economies were catching up with their Latin American counterparts until at least the middle of the decade, and after that point our index reveals that average efficiency in financial systems in transition economies surpasses those in Latin America.

\section{Trade liberalization}

The relationship between trade liberalization and FDI inflows is less straightforward. If trade flows are complements to FDI flows, ${ }^{24}$ then we should expect more FDI should be attracted to the countries with more liberalized trade regimes. On the other hand, if FDI is basically intended for tariff-jumping purposes, more restrictive trade regimes may be able to attract more FDI.

To measure the extent of trade liberalization, we construct an index based on two variables: average tariff rates and tariff dispersion. We use data from the World BankUNCTAD’s WITS system, for about 6,000 HS-6 digit product groups to calculate the tradeweighted average tariff and standard deviations yearly and for each of the 44 countries in our sample. $^{25}$

However, the drawback of using UNCTAD data is that we are faced with missing information for LACs for more recent years and for TEs for earlier years. To remedy this, we use also two supplementary data sources, Lora (2001) and the Heritage Foundation’s Economic Freedom of the World project (Gwartney, Lawson, and Samida, 2000). ${ }^{26}$ Once

\footnotetext{
${ }^{24}$ See Caves (1996) and Singh and Jun (1996) for complementarity between trade and FDI.

${ }^{25}$ It is noted that in the literature there exists much controversy regarding the construction of indexes of the restrictiveness of trade policy (Kee and others, 2006; Rodrik and Rodriguez, 2002). That said, in light of our data requirements, we choose to follow other studies in which trade reform is measured in this way and compared with other structural reforms.

${ }^{26}$ Lora (2001) covers the Latin American countries until 2000 and the Heritage Foundation's Economic Freedom of the World project covers most of the countries in our sample for years 1985,

(continued...)
} 
these were obtained, we applied the normalization above and took the arithmetic average of the two variables to generate an overall trade reform indicator.

Figure 5 shows the behavior of trade liberalization efforts over time. As it can be seen, our measure suggests that this dynamics was similar in the two regions over this time period, showing an almost continuous process of successive reduction of tariff levels as well as of their dispersion. Despite the very high levels of reform attained in the two regions, our indexes suggest that the extent of trade openness in LACs has gone somewhat further than that in TEs.

\section{Privatization}

The measure of privatization reform efforts is based on recently constructed data on privatization proceeds by the World Bank (Kikeri and Kolo, 2005). This provides detailed information on all privatization transactions across developing countries between 1990 and 2003. Privatization proceeds are defined as "all monetary receipts to the government resulting from partial and full divestitures (via asset sales or sale of shares), concessions, leases, and other arrangements” (2005, p.2). Notice that this excludes management contracts, new greenfield investments, and investments committed by new private operators as part of concession agreements.

More important, note that these data also do not reflect "voucher” privatization programs as these methods tend to generate little revenues for the government. Although this biases our privatization index downward, we note that there are few Eastern European countries that carried out extensive voucher privatization programs (notably, Czech Republic

1990, 1995, 2000, and yearly after 2000. Both data measure trade reform as a combination of average tariff levels and tariff dispersion across a large number of products and/or sectors. 
and Russia) and further that the choice of privatization methods has changed over time. In Russia, for example, voucher privatization was followed in the mid-1990s by the loans-forshares scheme which was abandoned in late 1990s in favor of a case-by-case privatization program (see, e.g., Bennett et al., 2004). On this basis, we believe this bias is not severe enough to discard this comprehensive and internationally comparable source. ${ }^{27}$

The privatization index results from aggregating privatization proceeds from the World Bank data for every country in our sample country per year, and applying the normalization described above.

Figure 6 shows these figures over time for the two regions. Note that: (a) with the exception of 1996 and 1997, our index suggests that privatization efforts were broadly comparable across the two regions, (b) somewhat surprisingly privatization efforts were more intense in Latin America than in Eastern Europe in the first half of the 1990s, (c) privatization efforts as measured by proceeds are more volatile in LACs than in TEs, and (d) there is a noticeable slow down of privatization activity after 1998 in the two regions but particularly in Latin America (Kikeri and Kolo, 2005).

\section{Institutions}

Host country institutions also influence investment decisions because they directly affect business operating conditions. The cost of investment consists of not only economic costs but also non-economic costs such as bribery and time lost in dealing with bureaucracy and local authorities. To assess the institutional aspects of business operation conditions in the host

\footnotetext{
${ }^{27}$ Available at http://rru.worldbank.org/Privatization/. As noted, our data set also contains information on whether or not the buyer is foreigner (company, individual, or consortium). Thus, we also construct a data series of government revenues from privatization that exclude all those transactions with a foreign buyer. All our main results below remain (including that for the role of privatization), which suggest that the link between reform (in this case privatization) and FDI inflows is not spurious in this sense.
} 
country, we use two main data sources: Polity IV and the International Country Risk Guide $(\mathrm{ICRG}){ }^{28}$

From Polity IV, we use the extent of constraints on the executive power and the actual number of years the current regime has been in power (xconst and durable, respectively in the original sources). These measures have been used widely in the economics literature (e.g., Acemoglu and others, 2001).

From the ICRG, we use the indexes of quality of the bureaucracy and the rule of law. ${ }^{29}$ These measures have also been used extensively in the economics literature (Gelos and Wei, 2005). The former is a 1 to 4 indicator reflecting the "autonomy from political pressure, institutional strength and quality of the bureaucracy” with higher ratings indicating a better bureaucracy along these lines. Also note that this measure is somewhat close to the corruption measure used by Wei (2000a, 2000b). High values for this variable implies good quality of bureaucracy and, thus, a lower cost for foreign investors as an honest government with transparent regulations is probably less likely to ask for bribes and side payments.

The indicator for the rule of law is coded from 1 to 6 with higher ratings reflecting the effectiveness of the legal system. ${ }^{30}$ A higher score in the rule of law implies better legal institutions. We expect that countries with better legal infrastructure will be able to attract more FDI.

\footnotetext{
${ }^{28}$ Available at http://www.cidcm.umd.edu/inscr/polity/ and http://www.icrgonline.com/, respectively.

${ }^{29}$ Notice that below we do not report results on durable from Polity IV for the sake of space. We have assessed other institutional dimensions from ICRG, such as their measure of corruption, of government stability, and of political and economic risks, but for space reasons also do not discuss these results as they are similar to the ones we report.

${ }^{30}$ It is originally called "law and order" in ICRG. The "law" sub-component assesses the strength and impartiality of the legal system and the "order" sub-component assesses popular observance of the law. Each sub-component equals half of the total.
} 
Not surprisingly, executive constraints seem to have been more effective in LACs than in TEs throughout the period of analysis. LACs' average is closer to the maximum category (which is seven) and indicates almost perfect parity of the executive with other legislative and judiciary power while the average for TEs is somewhat lower indicating only "substantial limitations on executive authority.” The rapid implementation of political reforms in TEs can be seen by the imposition of constraints on the executives which was virtually unconstrained under communism. This is reflected in our data in its brisk change between 1989 and 1990 for this region.

Regarding rule of law, TEs score better than LACs throughout our period of analysis. In both regions, we see a slight improvement in this regard between 1992 and 1998 but the values at the end of the period return to their 1989 levels. Finally, the ICRG's quality of the bureaucracy generates a slightly different picture. Although TEs seem to have better bureaucracies than LACs before 1997, from 1998 onwards these indexes overlap. This arguably reflects, on the one hand, successful public sector reforms in Latin America and cuts in government expenditures in transition economies. The lesson we take from these three series is that different dimensions of institutional development behave differently not only across regions but also over time. ${ }^{31}$

\section{Other Control Variables}

In addition to newly constructed variables, we also control for more traditional FDI determinants: market size, the level of development, macroeconomic stability, infrastructure, and natural resource abundance.

\footnotetext{
${ }^{31}$ Appendix Tables 1 and 2 report summary statistics and the correlation matrix, respectively. As it can be clearly seen from the latter, the correlations among our institutional variables are low.
} 
Depending on the motives for investment, investors value one factor over the other. For example, market-seeking investors will be attracted to a country with a large and fastgrowing local market. Resource-seeking investors will favor a country with abundant natural resources, everything else constant. Efficiency-seeking investors will weigh more heavily geographical proximity to the home country, to minimize transportation costs. ${ }^{32}$

Market-seeking FDI is mostly to serve the host country market. Market size is a measure of the size of potential demand in the host country. We expect FDI inflows (per worker and over GDP) to be greater in countries with larger domestic markets. For a proxy market size, we follow the literature and use Gross Domestic Product (in PPP terms), while the level of development is proxied by the level of real per capita GDP. The source of these two series is the IMF World Economic Outlook (WEO) database.

One indicator of a stable macroeconomic environment is price stability. Low inflation and prudent fiscal policies signal to investors the extent of government commitment and credibility. To proxy for stability, we use annual average inflation rates from WEO. Many transition and Latin American countries experienced high inflation after liberalizing prices in the late 1980s and early 1990s. Those countries that embarked on stabilization programs succeeded in bringing inflation under control rapidly. In this light, the lower the average inflation rate is in the host country, the more successful was the stabilization program and the faster GDP growth returned. Thus, we expect that foreign investment, ceteris paribus, will be attracted to countries with lower inflation rates.

Also from WEO, we construct a measure of natural resources dependence which is the percentage of oil and natural gas in total exports. Countries that are natural resources abundant may attract foreign investment in those industries, possibly diverting investment

\footnotetext{
${ }^{32}$ See Campos and Kinoshita (2002).
} 
from the manufacturing sector. ${ }^{33}$

Good infrastructure is an important factor for foreign investors to operate successfully, regardless of the type of FDI. Availability of main telephone lines is necessary to facilitate communication and we draw this information from the World Bank’s World Development Indicators (WDI). ${ }^{34}$

\section{The Results}

The objective of this section is to identify what factors explain the distribution of FDI across Latin American and transition economies for the period of 1989-2004. The novelty of our study is to explicitly introduce structural reforms as determinants of FDI. We argue that the omission of such factors may bias existing results.

\section{A. Baseline results}

Table 1 reports the regression results from the system-GMM due to Blundell and Bond (1998). ${ }^{35}$ The dependent variable is the ratio of FDI to GDP. Two specification tests - the Sargan test and the second-order correlation (SOC) test for the validity of instruments-are reported in the last two rows of each column.

As shown in columns 1 and 2, the results on the classical determinants of FDI are mostly consistent with the existing literature. Higher level of per capita income, stable

\footnotetext{
${ }^{33}$ Gyfason and Zoega (2001) find that abundant natural resources may crowd out physical capital and inhibit economic growth. See also Robinson, Torvik, and Verdier (2002).

${ }^{34}$ One alternative for the infrastructure variable is the percentage of paved roads in the country. But this variable can be misleading in developing countries: if there is one main road in the country and it is paved, then the value for this will be 100. Thus, large values may not necessarily indicate better infrastructure.

${ }^{35}$ We used all lagged values of the explanatory variables as instruments (in levels for the first difference equations and in differences for the level equation). The assumption of weak exogeneity for all variables is not rejected by the Sargan over-identification tests while the strict exogeneity of the same variables was rejected.
} 
macroeconomic environment reflected in low inflation, and sufficient infrastructure are positively related to FDI inflows. Resource abundance is another driver for FDI inflows in the region as seen in a positive and significant coefficient on log(fuel). However, it is important to note that market size proxied by $\log (\mathrm{GDP})$ fails to bear statistical significance and carries a negative sign. This implies that affiliate production in the host country is not necessarily intended for local sale but rather for export-platform. This is consistent with the findings in recent studies that vertical FDI is becoming more common than horizontal FDI. ${ }^{36}$ Alternatively, it might be the case that foreign investors are in search of monopoly power (Detragiache and others, 2005) and that they do not care about the domestic market size.

In columns 4 through 7 , we include structural reform variables. What is striking is the significance and relative magnitude of financial reform measured as bank efficiency as well as privatization. Note that the sizes of the coefficients of four types of structural reform are comparable as they are all normalized to one. In column 5, for example, the coefficient of bank efficiency is about three times as large as that of privatization indicating that financial development measured by bank efficiency is more important than the progress toward privatization on foreign investment decisions. Both the Sargan and SOC tests show that instruments are valid throughout the regressions.

The importance of a well-developed financial market is often cited as one of the prerequisites for economic growth. Tackling the financial globalization-growth puzzle, Prasad and others (2007) argue that foreign capital inflows including FDI can boost growth only when the recipient countries' financial markets are developed enough to channel foreign capital efficiently to finance productive investment. Alfaro and others (2004) report a similar

\footnotetext{
${ }^{36}$ Hanson and others (2001) and Grossman and Helpman (2003).
} 
finding for FDI that well-developed financial markets for a pooled are a precondition for the positive effects of FDI on economic development.

At the same time, this finding gives rise to a "paradox of finance" in the context of FDI. Why do multinational firms that are not clearly financially constrained systematically invest in countries in which such constraints are most relaxed?

In the closely related literature on FDI spillovers, recent studies find that FDI can generate spillovers mainly through intra-industry backward linkages rather than inter-industry horizontal linkages: the productivity of foreign firms can be increased by having efficient domestic suppliers in the upstream. ${ }^{37}$ In the current context, we could argue that foreign investors care about the efficiency of domestic financial market for its indirect benefit even if they do not raise capital locally. When the country has well-developed financial markets, it is more likely that local suppliers can invest in upgrading technology and machinery to provide better inputs. Thus, financial market development can be a good signal for the availability of potentially good suppliers.

Our results also show that privatization is other important structural reform that affects FDI inflows as shown in columns 5 through 7. Privatization measure is based on information from all privatization transactions above US\$50,000. That is, it contains the data on total revenues that privatized enterprise generated for the government per year. One concern is that the relationship we uncover is spurious because most of the privatizations that took place in these emerging economies comprise the selling of state owned enterprises to foreigners. Our data set also contains information on whether or not the buyer is foreign-origin. We construct an additional data series of government revenues from privatization that exclude all those

\footnotetext{
${ }^{37}$ Among others, see Smarzynska (2004), Gorodnichenko, Svejnar and Terrell (2007) and Lin and Saggi (2007).
} 
transactions with a foreign buyer. All our main results remain (including that for the role of privatization), which suggests that the link between greater private sector involvement (e.g., privatization) and FDI inflows is not spurious in this sense. ${ }^{38}$

As noted earlier, Russia and the Czech Republic were heavily reliant on vouchers and, thus, they received little privatization revenues. To differentiate voucher privatization, we also run the regressions excluding Russia and the Czech Republic. The results are, however, insensitive to the exclusion of the two countries.

For institutional quality, quality of bureaucracy consistently has a positive impact on FDI inflows for all countries while its statistical significance diminishes for the region-wise regressions shown in columns 6 and 7. The coefficients of executive constraints and rule of law are positive as expected, although they often fail to bear statistical significance. It is worth noting that rule of law is quite important for LACs (column 6), while quality of bureaucracy is the most important institutional quality for foreign direct investors in TEs (column 7). ${ }^{39}$

It is noteworthy that the difference between LACs and TEs is seen in trade liberalization. The progress of trade liberalization is an impetus to FDI inflows only in LACs, but not in TEs.

\section{B. Decomposition of the financial sector reform}

The previous table shows that an efficient banking sector helps the country attract more FDI inflows. One might argue that the indicators of financial sector reform—overall financial development and bank efficiency—reflect the level of financial development rather than

\footnotetext{
${ }^{38}$ We also find no evidence of Granger-causality between our privatization index and FDI inflows (over GDP or per worker). These results are also available from the authors upon request.

${ }^{39}$ Fan and others (2007) report that FDI inflows correlates with various institutional variables similar to ours- executive constraints, rule of law, and government's good track record.
} 
reform efforts. Thus, our results might simply indicate that FDI is attracted to the country with a financial market that had been already well-developed.

In order to test if reform efforts encourage more FDI inflows rather than reform outcomes (e.g., the current level of financial development), we report in Table 2 with other variables of financial sector reforms from the alternative data source. ${ }^{40}$ One drawback is that we lose quite a few observations. Nevertheless, this would serve us a robustness check on the importance of structural reforms in the financial sector in explaining FDI inflows.

Eight additional financial reform variables are shaded in gray. The definitions of these variables are found in Appendix 2. Financial liberalization index is constructed as an overall average of seven financial reform variables. We also include overall financial development to control for the current level of financial sector development.

Columns 1 to 7 report the coefficients on each component of the financial reform variables when included separately in the regressions. They report that the ones that are associated with higher FDI inflows are supervision, creditceilings, and secruitiesmarkets. That is, FDI is attracted to a country with fewer restrictions on the expansion of bank credits, well-supervised banking sector, and more liberalized securities markets.

Columns 8 to 10 report the results when we include financial liberalization index (the composite of all financial reform variables). For all countries, financial liberalization index is positive and significant. The same result holds for TEs. However, financial liberalization index is no longer important for LACs. We also tried with each of the financial reform variables for LACs but they fail to bear statistical significance.$^{41}$ For LACs, not financial sector reforms but privatization is a driving force behind FDI inflows.

\footnotetext{
${ }^{40}$ Abiad, Detragiache, and Tressel (2007) “A New Database of Financial Reforms”.

${ }^{41}$ Results available upon request.
} 
In sum, the efforts of developing a well-functioning financial sector do indeed encourage more FDI inflows even after controlling for the current level of financial development: the progress in structural reforms in the financial sector can send a good signal to foreign investors even if the financial market is not yet deep.

We found from the above result that financial sector reforms are an important driver for FDI. One important concern regarding this result is the possibility of reverse causality. Does FDI promote the efficiency of the financial sector? Or is it that FDI is attracted by an efficient financial sector? If foreign banks are generally more efficient than domestic banks, the entry of foreign banks can be responsible for an improvement in financial sector efficiency and foreign direct investment.

Our strategy is to collect additional information on the share of foreign ownership in the financial sector and run split-sample regressions to check whether such variation does affect our results. Although we cannot distinguish FDI inflows in the financial sector and in the non-financial sector, we have the data on the share of foreign ownership in the financial sector. ${ }^{42}$

In Table 3, we divided the sample into two subgroups, nonfinancial FDI and financial FDI. If the observation has a major foreign share (greater than 20 percent), then it is classified as financialFDI. If a foreign share is less than 20 percent, it is grouped as nonfinancial FDI. ${ }^{43}$

The results in the first two columns in Table 3 show that, for all countries, financial liberalization index remains to be significant only for the countries with large foreign

\footnotetext{
42 Data were drawn from BankScope.

${ }^{43}$ We also conducted the Granger-causality tests in order to deal with the endogeneity. The tests show that financial reforms drive FDI inflows but not the other way around. We also did the standard IV estimation by using a number of de jure financial reform indexes taken from Abiad and others (2007) and found that bank efficiency remains significant in the IV results. These results are available from the authors upon request.
} 
presence in the financial sector. Together with the insignificance of overall financial development, it implies that the policies to liberalize the financial markets rather than the level of financial development are more important for FDI inflows particularly when the country receives much FDI in the financial sector. In region-wise regressions, the difference between nonfinancial and financial FDI disappears both for LACs and TEs. Only for TEs, financial liberalization efforts positively influence FDI inflows. However, we need caution in interpreting the region-wise results as they can be due to insufficient number of observations.

\section{Robustness checks}

So far we find that institutional qualities have a limited impact on FDI inflows in the data. Namely, the quality of bureaucracy seems to play a role in attracting FDI for all countries while rule of law is important only for LACs. As it is well-known that the institutional variables tend to be closely related with one another, the inclusion of all institution variables at once might make it difficult to see which institutional attribute is more important. ${ }^{44}$

Table 4 reports results with the institutional variables included one at a time to address this issue. In addition, we include other institutional variables such as corruption, political risk, and indicator of polity durability. The aspects of institutional qualities that are closely related to FDI inflows are bureaucracy and executive constraints. Durability is another important factor. Rule of law remains statistically insignificant (column 3). We did the same sensitivity analysis for both region groups, LACs and TEs. Again, the baseline results remain robust. In LACs, rule of law is the only institutional variable that matters. In TEs, the quality of bureaucracy is the only variable with significance.

\footnotetext{
${ }^{44}$ The correlation coefficients among institutional variables are not so large. See Appendix 2.
} 
Another sensitivity analysis is carried out for the infrastructure variable in Table 5. In the baseline regressions, we use the number of main telephone lines as a proxy for communication technology. One might argue that fixed telephone lines lose its importance for countries that are modernized enough to take advantage of cellular networks. Though we do not have that information in the data, alternatively, we use the number of computers per 1000 people. Table 5 shows that the main results hold by replacing telephone lines with computers: the country with sufficient provisions of infrastructure attracts FDI. ${ }^{45}$

In sum, our main findings on structural reforms and institutions withstand robustness tests. We find that the efficiency of the banking sector and privatization are two areas of structural reforms important for FDI investors. Good institutions also play a role via the quality of bureaucracy and rule of law for TEs and LACs, respectively.

\section{ConCLusions}

Since the late 1980s, structural reforms have been implemented in unparalleled scale across the developing world while foreign direct investment (FDI) became one of the main components of private capital flows. The literature has not yet fully investigated their relationship in large part because of the lack of measures of structural reforms comparable over time and across regions. More recently, the literature has given weight to the identification of possible channels through which FDI may be made more effective such as a minimum threshold level of absorptive capacity such as human capital in the host country (Borensztein et al., 1998). The implementation of structural reforms can work in similar way as structural reforms can improve business conditions and the investment climate.

\footnotetext{
${ }^{45}$ We also included the uses of internet as a proxy for infrastructure but the number of observations drops significantly due to missing observations. Results available upon request.
} 
In this paper we construct the new data set on structural reform indices for 19 Latin American and 25 transition economies from 1989 to 2003. We go beyond the identification of the effects of selective individual reforms and try to provide a more comprehensive assessment of these links by asking which reforms matter vis-à-vis FDI and whether the effects of reform efforts differ in systematic ways from reform outcomes as well as from other standard FDI determinants.

Our main finding from the regression analyses is a robust empirical relationship from structural reforms to FDI. Also, we find a stronger effect from financial sector reforms and privatization than from trade liberalization. When we had measures of both reform efforts and reform outcomes (e.g., financial reform), we find that the effect of reform outcomes is fragile (in terms of the overall degree of financial development), while that of reform efforts tend to be more powerful. We conclude that this set of determinants of FDI inflows-financial reform, privatization, level of development and quality of the infrastructure-is robust to different measures of reform, different estimators, split samples, and potential endogeneity and omitted variables biases.

We highlight three extensions of our study. First, one could further extend the analysis to re-investigate the long-term implications of FDI on growth after taking into account structural reforms. In particular, our findings point to the direction that financial sector reform may be a key factor in enhancing the benefits of foreign capital inflows. Second, it would be interesting to assess whether our findings hold as well for developed and for other groups of developing countries (Africa, Middle East and Asia), although this would require a substantial data collection effort. Third, as previously mentioned, the choice of structural reforms can be extended to have a broader coverage such as labor market and product market liberalization, tax policy, as well as changes in the regulatory framework. 


\section{References}

Abed, G.T. and Davoodi, H.R., 2000, "Corruption, Structural Reforms, and Economic Performance in the Transition Economies," IMF Working Paper 00/132

Abiad, A., E. Detragiache, and T. Tressel, 2007, “A New Database of Financial Reforms,” unpublished, International Monetary Fund.

Acemoglu, D. and J. Robinson, 2001, “A Theory of Political Transitions,” American Economic Review, 91, pp. 938-63.

Acemoglu, D., S. Johnson, J. Robinson, and Y Thaicharoen, 2003, "Institutional Causes, Macroeconomic Symptoms: Volatility, Crises and Growth,” Journal of Monetary Economics, 50, pp. 49-123.

Alfaro, L., A. Chanda, S. Kalemli-Ozcan, and S. Sayek, 2004, "FDI and economic growth: the role of local financial markets,” Journal of International Economics, 64, pp. 89112.

Antras, P., 2003, “Firms, Contracts, and Trade Structure,” Quarterly Journal of Economics, 118, No. 4, pp. 1375-1418.

Arellano, M., and S. Bond, 1991, "Some Tests of Specification for Panel Data: Monte Carlo Evidence and an Application to Employment Equation,” Review of Economic Studies, 58, pp. 277-97.

Banks, A., 2005, “Banks' Cross-National Time-Series Data Archive,” electronic database.

Barrell, R., and N. Pain, 1999, "Domestic Institutions, Agglomerations, and Foreign Direct Investment in Europe,” European Economic Review, 43, pp. 925-34.

Beck, Thorsten, Asli Demirgüç-Kunt and Ross Levine, 2000, "A New Database on Financial Development and Structure," World Bank Economic Review, 14, pp. 597-605.

Bengoa, M., and B. Sanchez-Robles, 2003, "Foreign direct investment, economic freedom and growth: new evidence from Latin America,” European Journal of Political Economy, 19, No. 3, pp. 529-45.

Bennett, J., S. Estrin, J. Maw, and G. Urga, 2004, "Privatization Methods and Economic Growth in Transition Economies,” CEPR Discussion Paper No. 4291.

Bevan, A., and S. Estrin, 2000, "The Determinants of Foreign Direct Investment in Transition Economies,” University of Michigan, William Davidson Institute, DP 342.

Bevan, A., S. Estrin and K Meyer, 2004, "Foreign Investment Location and Institutional Development in Transition Economies,” International Business Review, 13, pp. 43-64. 
Blundell, R., and S. Bond., 1998, "Initial Conditions and Moment Restrictions in Dynamic Panel Data Models.” Journal of Econometrics, 87(1), pp. 115-43.

Blonigen, B., 2005, “A Review of the Empirical Literature on FDI Determinants,” NBER Working Paper No. W11299.

Borensztein, E., J. DeGregorio, and J-W. Lee, 1998, “How Does Foreign Direct Investment Affect Economic Growth?” Journal of International Economics, 45, pp. 115-35.

Calvo, G., 2003, "Explaining Sudden Stops, Growth Collapse and BOP Crises: The Case of Distortionary Output Taxes,” NBER Working Paper No. W9864.

Campos, N. F., and F. Coricelli, 2002, "Growth in Transition: What We Know, What We Don’t, and What We Should,” Journal of Economic Literature, Vol. XL (3),pp. 793836.

— Transition Economies,” IMF Working Paper 03/228.

Caves, R., 1996, Multinational Enterprise and Economic Analysis, 2nd ed. (Cambridge: Cambridge University Press).

Cheng, L., and Y. Kwan, 2000, "What Are the Determinants of the Location of Foreign Direct Investment? The Chinese Experience,” Journal of International Economics, 51, pp. 379-400.

De Gregorio, J., 1992, “Economic Growth in Latin America,” Journal of Development Economics 39, pp. 58-84.

De Melo, M., C. Denizer, A. Gelb, and S. Tenev, 1997, "Circumstance and Choice: The Role of Initial Conditions Policies in Transition Economies,” World Bank WPS 1866.

Detragiache, E., P. Gupta, and T. Tressel, 2005, “Finance in Lower-Income Countries: An Empirical Exploration,” IMF Working Paper 05/167.

Dewatripont, M and G Roland, 1995, “The Design of Reform Packages under Uncertainty,” American Economic Review, 85 (5), pp. 1207-23.

Dunning, J., 1993, Multinational Enterprises and the Global Economy (Harlow: AddisonWesley).

European Bank for Reconstruction and Development, 2000, Transition Report 2000 (London: European Bank for Reconstruction and Development).

Forbes, K., 2006, “Capital Account Liberalization: A Vehicle for Growth?” Presented at IMF Conference: How does capital account liberalization affect economic growth? Washington. 
Garibaldi, P., N. Mora, R. Sahay, and J. Zettelmeyer, 2001, "What Moves Capital to Transition Economies?” IMF Staff Papers, 48, pp. 109-45.

Gastanaga, V, J. Nugent, and B Pashamova, 1998, “Host Country Reforms and FDI Inflows: How Much Difference do They Make?” World Development 27 (7), pp. 1299-1314.

Gelos, G. and S. Wei, 2005, “Transparency and International Portfolio Holdings,” Journal of Finance, 60, pp. 29-87.

Gorodnichenko, Y., J. Svejnar, and K.Terrell, 2007, "When Does FDI Have Positive Spillovers? Evidence from 17 Emerging Market Economies,” Bonn, IZA Discussion Papers No. 3079.

Gylfason, T., and G. Zoega, 2001, "Natural Resources and Economic Growth: The Role of Investment,” CEPR Discussion Paper No. 2743.

Gwartney, J., Lawson, R., and D. Samida, 2000, Economic Freedom of the World, Heritage Foundation and Fraser Institute.

Hanson, G., R. Mataloni, Jr., and M. Slaughter, 2001, "Expansion Strategies of U.S. Multinational Firms," NBER Working Paper 8433, National Bureau of Economic Research.

International Monetary Fund. World Economic Outlook, various years.

Javorcik, B. S., 2004, "Does Foreign Direct Investment Increase the Productivity of Domestic Firms? In Search of Spillovers through Backward Linkages," American Economic Review, 94(3), pp. 605-27.

Johnson, S., P. Boone, A. Breach, and E. Friedman, 2000, “Corporate Governance in the Asian Financial Crisis,” Journal of Financial Economics, 58, pp. 141-86.

Kaminsky, G., and C. Reinhart, 2000, “On crises, contagion, and confusion,” Journal of International Economics, 51, No. 1, pp. 145-68.

Kee, H., A. Nicita, and M. Olarreaga, 2006, “Estimating Trade Restrictiveness Indices,” CEPR Discussion Paper No. 5576.

Kikeri, S., and F. Kolo, 2005, “Privatization: Trends and Recent Developments,” World Bank WPS 3765.

Kose, A., E. Prasad, K. Rogoff, and S. Wie, 2006, “Financial Globalization: A Reappraisal,” IMF Working Paper WP/06/189.

Loayza, N., and R. Soto, 2004, “On the Measurement of Market-Oriented Reforms,” World Bank Policy Research Working Paper Series No.3371. 
Lora, E., 1998, "What Makes Reforms Likely? Timing and Sequencing of Structural Reforms in Latin America,” Inter-American Development Bank, Working Paper 424.

Lora, E., U. Panizza, and M. Quispe-Agnoli, 2003, “Reform Fatigue: Symptons, Reasons, Implications,” Inter-American Development Bank, unpublished.

La Porta, R., F. Lopez-de-Silanes, A. Shleifer, and R. Vishny, 1998, “Law and Finance,” Journal of Political Economy, 106(6), pp. 1113-55.

Lin. P. and K. Saggi, 2007, "Multinational Firms, Exclusivity, and the Degree of Backward Linkages,” Journal of International Economics 71, pp. 206-20.

Lipsey, R., 2006, “Measuring Foreign Direct Investment,” CUNY/NBER, unpublished.

Lucas, Jr., R.E., 1988, “The Mechanics of Economic Development,” Journal of Monetary Economics, 22, pp. 3-42.

—_ 1990, "Why Doesn’t Capital Flow From Rich to Poor Countries?” American Economic Review Paper and Proceedings, 80, pp. 92-6.

Lucas, R., 1993, “On the Determinants of Direct Foreign Investment: Evidence from East and Southeast Asia,” World Development, 21(3), pp. 391-406.

Polity IV Project, 2002, “Political Regime Characteristics and Transitions, 1800-2002,” available at http://www.cidcm.umd.edu/inscr/polity/.

Portes, R., H. Rey, and Y. Oh, 2001, "Information and Capital Flows: The Determinants of Transactions in Financial Assets,” European Economic Review, 45, pp. 783-96.

Prasad, E., R. Rajan, and A. Subramanian, 2007, "Foreign Capital and Economic Growth,” Brookings Papers on Economic Activity.

Prasad, E., K. Rogoff, S. Wei, and M.A. Kose, 2003, Effects of Financial Globalization on Developing Countries: Some Empirical Evidence, IMF Occasional Paper 220 (Washington: International Monetary Fund).

Resmini, L., 2000, “The Determinants of Foreign Direct Investment in the CEECs ,” Economics of Transition, 8 (3), pp. 665-89.

Robinson, J., R. Torvik, and T. Verdier, 2002, "Political Foundations of the Resource Curse,” CEPR Discussion Paper No. 3422.

Rodrik, D., 1996, “Understanding Economic Policy Reform,” Journal of Economic Literature 34 (1), pp. 9-41.

Rodrik, D., and F. Rodríguez, 2001, “Trade Policy and Economic Growth: A Skeptics Guide to the Cross-National Evidence.” in B. Bernanke and K. Rogoff (editors), NBER Macroeconomics Annual 2000, 15, pp. 261-325. 
Sachs, J., and A. Warner, 1995, "Economic Reform and the Process of Global Integration” Brookings Papers on Economic Activity, 1, pp. 1-118.

Singh, A., A. Belaisch, C. Collyns, P. Masi, R. Krieger, G. Meredith, and R. Rennhack, 2005, "Stabilization and Reform in Latin America: A Macroeconomic Perspective on the Experience Since the Early 1990s,” IMF Occasional Paper 238.

Singh, A., 2006, "Macroeconomic Volatility: The Policy Lessons from Latin America," International Monetary Fund Working Paper WP/06/166.

Singh, H., and K. Jun, 1996, “The Determinants of Foreign Direct Investment in Developing Countries,” Transnational Corporations 5, No. 2, pp. 67-105.

UNCTAD, 2002, World Investment Report 2002.

Trevino, L., J. Daniels, and H. Arbeláez, 2002, "Market reform and FDI in Latin America: An empirical investigation,” Transnational Corporations

Wacziarg, R. and K. Welch, 2003, “Trade Liberalization and Growth: New Evidence,” NBER Working Paper 10152.

Wei, S. J., 2000a, “How Taxing is Corruption on International Investors?” Review of Economics and Statistics, 82 (1), pp. 1-11.

_ 2000b, “Local Corruption and Global Capital Flows,” Brookings Papers on Economic Activity 2, , pp. 303-54.

Wheeler, D., and A. Mody, 1992, "International Investment Location Decisions: The Case of U.S. firms,” Journal of International Economics, 33, pp. 57-76. 
Figure 1. Foreign Direct Investment Inflows over GDP, Latin American and Transition Economies, 1989-2004 (both in constant US\$ billions)

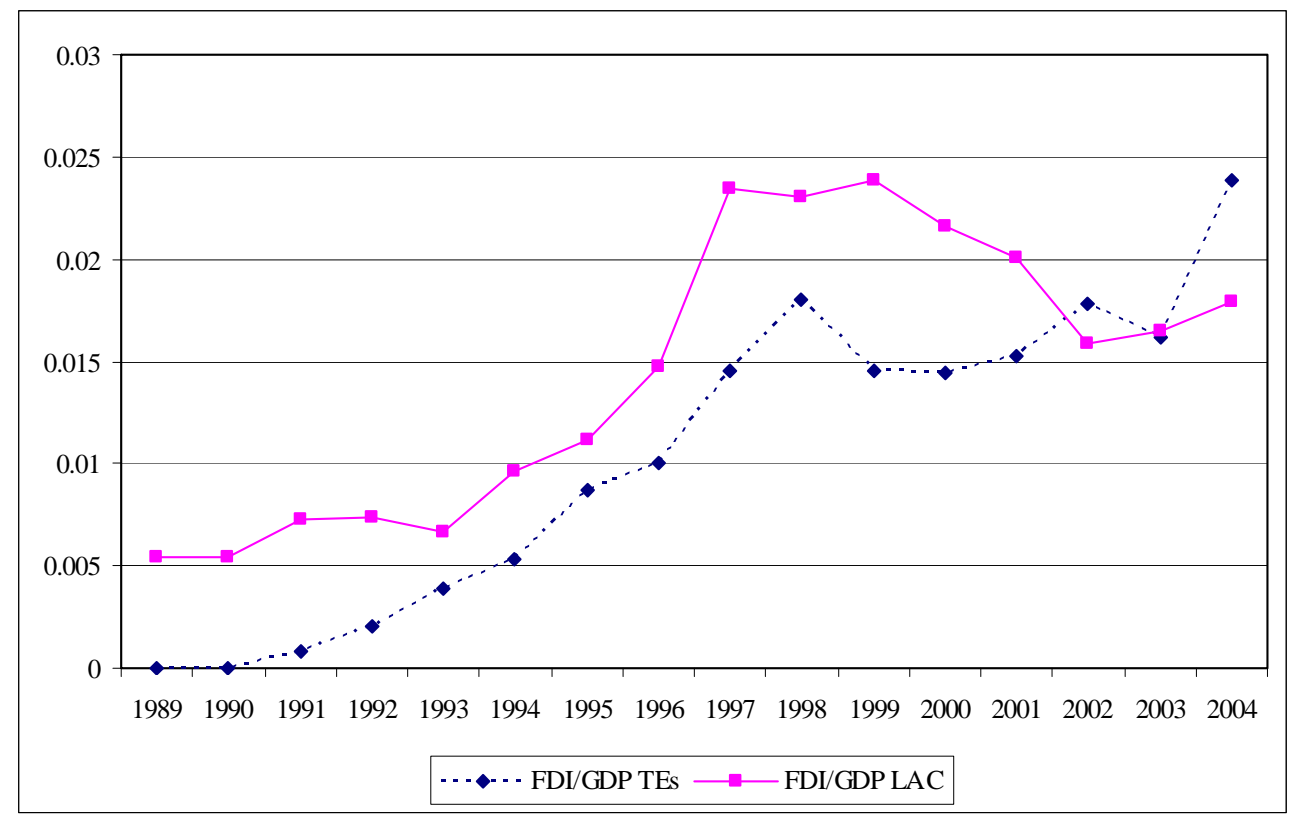

Figure 2. Foreign Direct Investment Inflows per Worker, Latin American and Transition Economies, 1989-2004

(in constant US\$ billions)

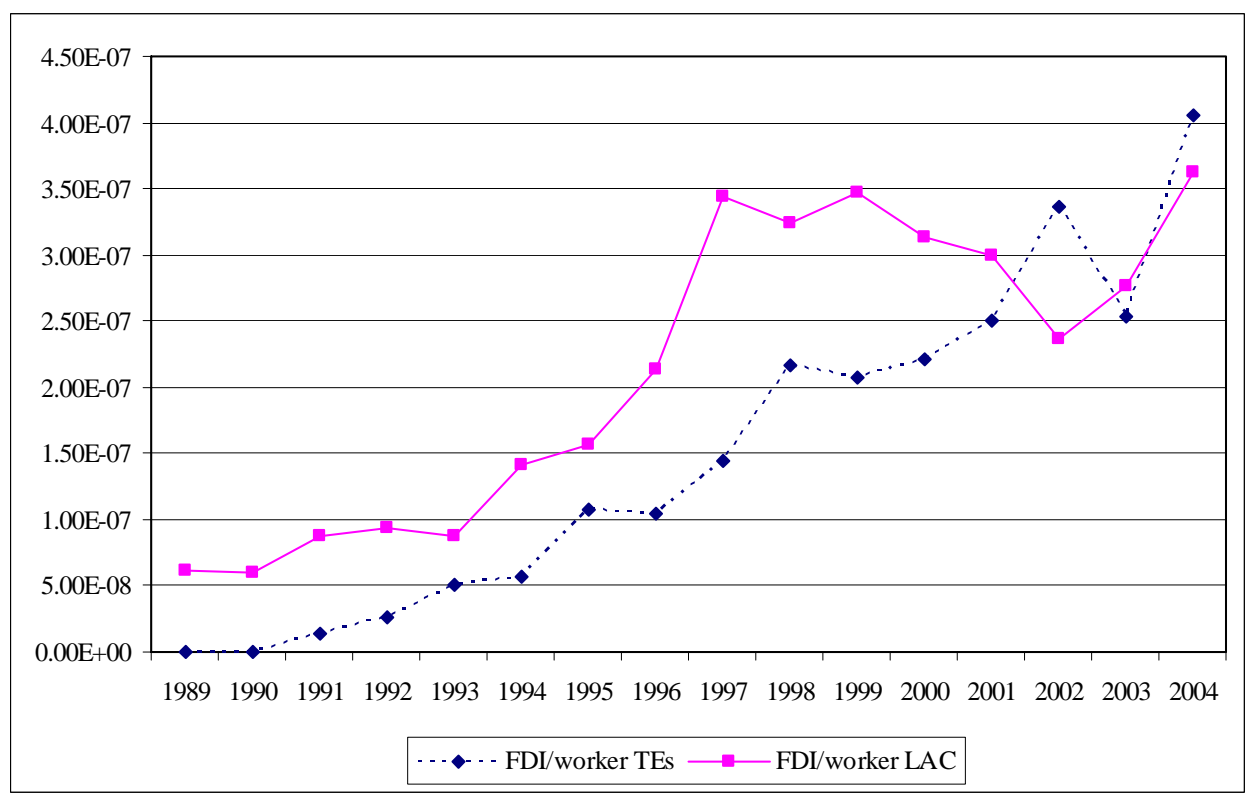


Figure 3. Overall Financial Reform Index

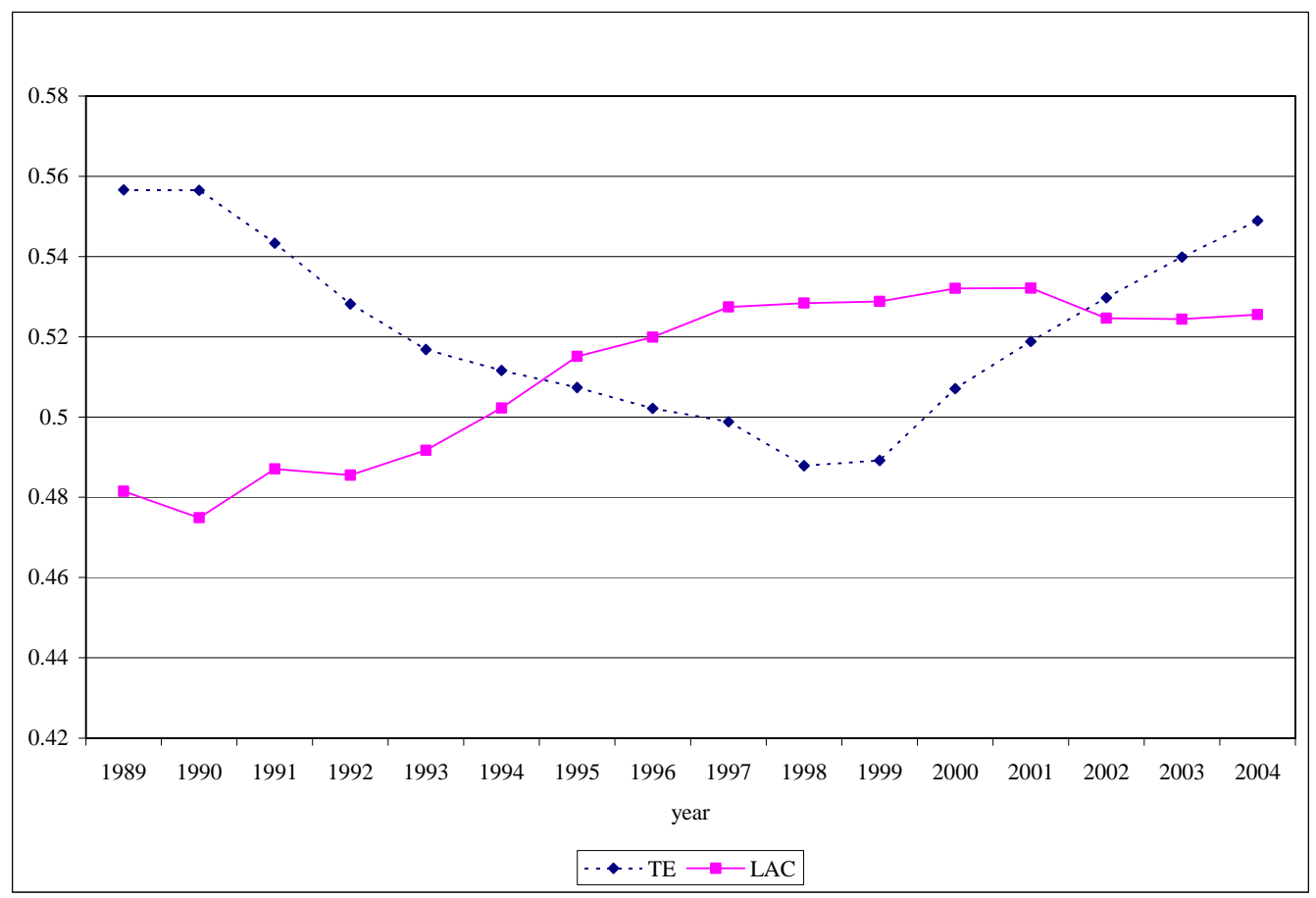

Figure 4. Index of Efficiency of Financial Intermediation

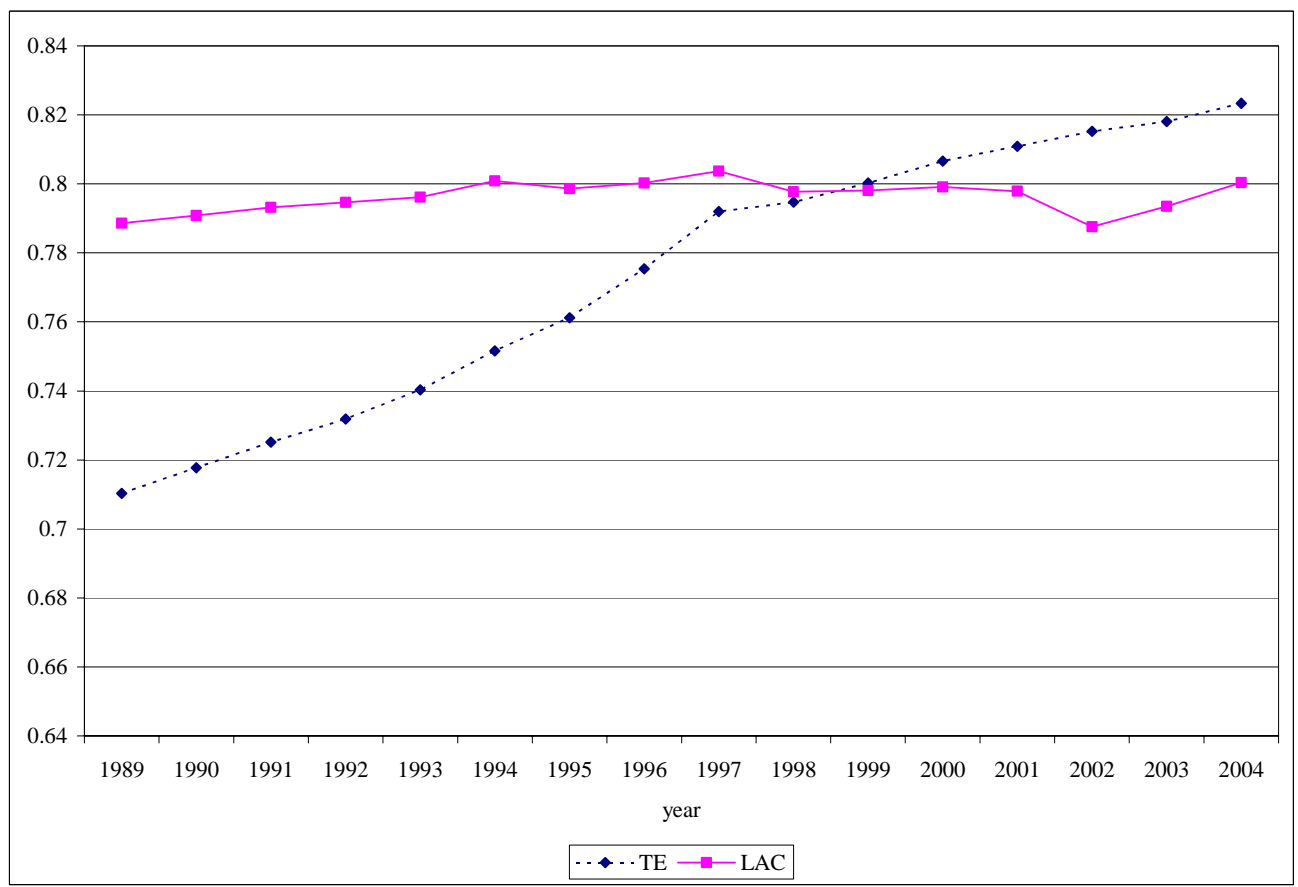


Figure 5. Trade Liberalization Index

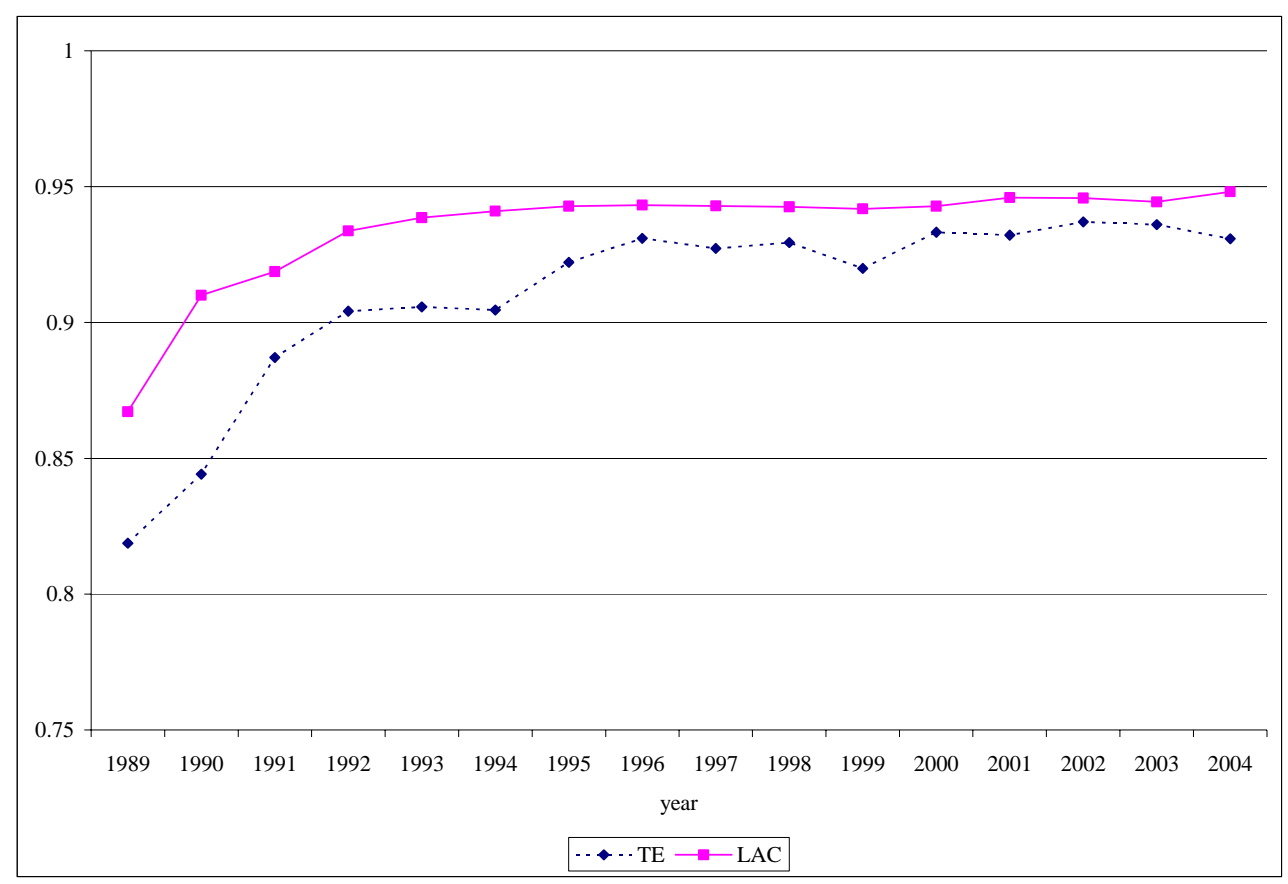

Figure 6. Privatization Index

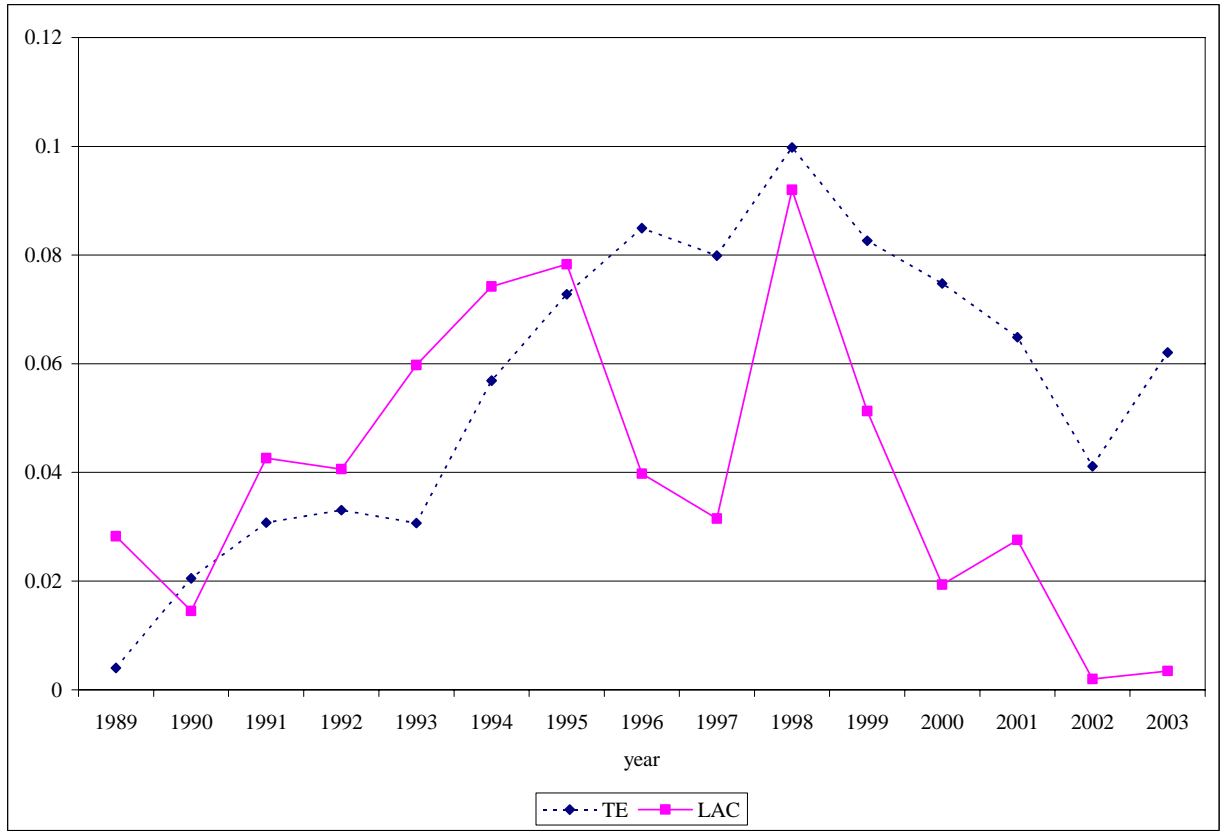


Table 1. Determinants of FDI: Baseline Model

Dependent variable $=\log (\mathrm{FDI} / \mathrm{GDP})$

\begin{tabular}{|c|c|c|c|c|c|c|c|}
\hline & $\begin{array}{c}1 \\
\text { ALL }\end{array}$ & $\begin{array}{c}2 \\
\text { ALL }\end{array}$ & $\begin{array}{c}3 \\
\text { ALL }\end{array}$ & $\begin{array}{c}4 \\
\text { ALL }\end{array}$ & $\begin{array}{c}5 \\
\text { ALL }\end{array}$ & $\begin{array}{c}6 \\
\text { LAC }\end{array}$ & $\begin{array}{c}7 \\
\mathrm{TE}\end{array}$ \\
\hline $\log (\mathrm{GDP})$ & $\begin{array}{c}-0.167 * * * \\
{[0.041]}\end{array}$ & $\begin{array}{c}-0.515^{* * *} \\
{[0.096]}\end{array}$ & $\begin{array}{c}-0.432^{* * *} \\
{[0.097]}\end{array}$ & $\begin{array}{c}-0.413^{* * *} \\
{[0.098]}\end{array}$ & $\begin{array}{c}-0.383 * * * \\
{[0.096]}\end{array}$ & $\begin{array}{c}-1.161^{* * *} \\
{[0.17]}\end{array}$ & $\begin{array}{c}-0.622^{* * *} \\
{[0.17]}\end{array}$ \\
\hline log(GDP per capita) & $\begin{array}{c}0.499 * * * \\
{[0.075]}\end{array}$ & $\begin{array}{c}0.473 * * * \\
{[0.073]}\end{array}$ & $\begin{array}{c}0.271^{* * *} \\
{[0.089]}\end{array}$ & $\begin{array}{c}0.285^{* * *} \\
{[0.093]}\end{array}$ & $\begin{array}{l}0.218^{* *} \\
{[0.090]}\end{array}$ & $\begin{array}{c}-0.269 * * \\
{[0.13]}\end{array}$ & $\begin{array}{c}0.17 \\
{[0.19]}\end{array}$ \\
\hline $\log$ (inflation) & $\begin{array}{c}-0.237 * * * \\
{[0.035]}\end{array}$ & $\begin{array}{c}-0.176^{* * * *} \\
{[0.035]}\end{array}$ & $\begin{array}{c}-0.180 * * * \\
{[0.034]}\end{array}$ & $\begin{array}{c}-0.139 * * * \\
{[0.039]}\end{array}$ & $\begin{array}{c}-0.153^{* * *} \\
{[0.038]}\end{array}$ & $\begin{array}{c}-0.101 * * \\
{[0.050]}\end{array}$ & $\begin{array}{l}-0.0777 \\
{[0.052]}\end{array}$ \\
\hline log(telephone lines) & & $\begin{array}{c}0.341 * * * \\
{[0.090]}\end{array}$ & $\begin{array}{c}0.252 * * * \\
{[0.092]}\end{array}$ & $\begin{array}{c}0.274 * * * \\
{[0.092]}\end{array}$ & $\begin{array}{c}0.259 * * * \\
{[0.091]}\end{array}$ & $\begin{array}{c}1.192 * * * \\
{[0.18]}\end{array}$ & $\begin{array}{c}0.460 * * * \\
{[0.15]}\end{array}$ \\
\hline $\log$ (fuel) & & $\begin{array}{c}0.0513^{*} \\
{[0.028]}\end{array}$ & $\begin{array}{c}0.0734 * * * \\
{[0.028]}\end{array}$ & $\begin{array}{c}0.0817 * * * \\
{[0.028]}\end{array}$ & $\begin{array}{c}0.0570 * * \\
{[0.027]}\end{array}$ & $\begin{array}{c}0.0645^{* *} \\
{[0.028]}\end{array}$ & $\begin{array}{l}0.0357 \\
{[0.069]}\end{array}$ \\
\hline Qual. of Bureaucracy & & & $\begin{array}{c}0.216 * * * \\
{[0.074]}\end{array}$ & $\begin{array}{c}0.165^{* *} \\
{[0.077]}\end{array}$ & $\begin{array}{c}0.155^{* *} \\
{[0.078]}\end{array}$ & $\begin{array}{l}0.0266 \\
{[0.10]}\end{array}$ & $\begin{array}{l}0.185 \\
{[0.14]}\end{array}$ \\
\hline Executive constraints & & & $\begin{array}{c}0.0316 \\
{[0.039]}\end{array}$ & $\begin{array}{c}0.0376 \\
{[0.041]}\end{array}$ & $\begin{array}{l}0.0851 * \\
{[0.047]}\end{array}$ & $\begin{array}{c}-0.152 * * \\
{[0.077]}\end{array}$ & $\begin{array}{c}0.074 \\
{[0.064]}\end{array}$ \\
\hline Rule of Law & & & $\begin{array}{c}0.0389 \\
{[0.040]}\end{array}$ & $\begin{array}{c}0.0343 \\
{[0.041]}\end{array}$ & $\begin{array}{l}0.0241 \\
{[0.041]}\end{array}$ & $\begin{array}{c}0.349 * * * \\
{[0.063]}\end{array}$ & $\begin{array}{c}-0.0221 \\
{[0.090]}\end{array}$ \\
\hline Overall fin. development & & & & $\begin{array}{l}-1.105 \\
{[0.82]}\end{array}$ & $\begin{array}{l}-1.018 \\
{[0.82]}\end{array}$ & $\begin{array}{l}-0.791 \\
{[1.13]}\end{array}$ & $\begin{array}{l}0.107 \\
{[1.54]}\end{array}$ \\
\hline Bank efficiency & & & & $\begin{array}{c}4.485^{* * *} \\
{[1.49]}\end{array}$ & $\begin{array}{c}3.048^{* *} \\
{[1.43]}\end{array}$ & $\begin{array}{c}4.132 * * \\
{[1.62]}\end{array}$ & $\begin{array}{c}9.180 * * * \\
{[2.47]}\end{array}$ \\
\hline Trade liberalization & & & & & $\begin{array}{l}1.835 \\
{[1.47]}\end{array}$ & $\begin{array}{l}5.582 * \\
{[2.88]}\end{array}$ & $\begin{array}{l}-1.796 \\
{[1.62]}\end{array}$ \\
\hline Privatization & & & & & $\begin{array}{c}1.133 * * * \\
{[0.37]}\end{array}$ & $\begin{array}{c}1.410^{* * *} \\
{[0.51]}\end{array}$ & $\begin{array}{c}1.512^{* * *} \\
{[0.47]}\end{array}$ \\
\hline Observations & 355 & 315 & 315 & 315 & 298 & 182 & 116 \\
\hline Number of ccode & 33 & 33 & 33 & 33 & 31 & 15 & 16 \\
\hline Sargan Test & 0.55 & 0.64 & 0.53 & 0.66 & 0.27 & 0.31 & 0.18 \\
\hline SOC & 0.42 & 0.46 & 0.39 & 0.49 & 0.21 & 0.65 & 0.09 \\
\hline
\end{tabular}

Regressions use the system-GMM estimator. All regressions include a constant term. Robust standard errors are reported in brackets. Instruments used are $\log$ (GDP), $\log$ (GDP per capita), log(inflation), log(telephone lines), $\log ($ fuel), quality of bureaucracy, executive constraints, rule of law, overall financial development, bank efficiency, trade liberalization, and privatization: for the difference equations, all in lagged levels and, for the level equation, in first difference. $* * *, * *$, and $*$ denote significance at the $1 \%, 5 \%$, and $10 \%$ level, respectively. 
Table 2. Determinants of FDI: Decomposition of Financial Liberalization

[Dependent variable $=\log (\mathrm{FDI} / \mathrm{GDP})]$

\begin{tabular}{|c|c|c|c|c|c|c|c|c|c|c|}
\hline & $\begin{array}{c}1 \\
\text { ALL } \\
\end{array}$ & $\begin{array}{c}2 \\
\text { ALL } \\
\end{array}$ & $\begin{array}{c}3 \\
\text { ALL } \\
\end{array}$ & $\begin{array}{c}4 \\
\text { ALL } \\
\end{array}$ & $\begin{array}{c}5 \\
\text { ALL } \\
\end{array}$ & $\begin{array}{c}6 \\
\text { ALL } \\
\end{array}$ & $\begin{array}{c}7 \\
\text { ALL } \\
\end{array}$ & $\begin{array}{c}8 \\
\text { ALL } \\
\end{array}$ & $\begin{array}{c}9 \\
\text { LAC } \\
\end{array}$ & $\begin{array}{l}10 \\
\mathrm{TE}\end{array}$ \\
\hline $\log (G D P)$ & $\begin{array}{c}-0.475 * * * \\
{[0.13]}\end{array}$ & $\begin{array}{c}-0.297 * * \\
{[0.13]}\end{array}$ & $\begin{array}{c}-0.417 * * * \\
{[0.12]}\end{array}$ & $\begin{array}{c}-0.393^{* * *} \\
{[0.12]}\end{array}$ & $\begin{array}{c}-0.432 * * * \\
{[0.12]}\end{array}$ & $\begin{array}{c}-0.615^{* * *} \\
{[0.17]}\end{array}$ & $\begin{array}{c}-0.356 * * * \\
{[0.12]}\end{array}$ & $\begin{array}{c}-0.335^{* * *} \\
{[0.12]}\end{array}$ & $\begin{array}{c}-1.489 * * * \\
{[0.24]}\end{array}$ & $\begin{array}{c}-0.486^{* * *} \\
{[0.19]}\end{array}$ \\
\hline log(GDP per capita) & $\begin{array}{c}0.445^{* * *} \\
{[0.11]}\end{array}$ & $\begin{array}{c}0.407^{* * *} \\
{[0.11]}\end{array}$ & $\begin{array}{c}0.428 * * * \\
{[0.11]}\end{array}$ & $\begin{array}{c}0.416^{* * *} \\
{[0.11]}\end{array}$ & $\begin{array}{c}0.366^{* * *} \\
{[0.11]}\end{array}$ & $\begin{array}{c}1.622 * * * \\
{[0.20]}\end{array}$ & $\begin{array}{c}0.343^{* * *} \\
{[0.12]}\end{array}$ & $\begin{array}{c}0.363 * * * \\
{[0.12]}\end{array}$ & $\begin{array}{l}-0.239 \\
{[0.17]}\end{array}$ & $\begin{array}{c}0.917 * * * \\
{[0.27]}\end{array}$ \\
\hline $\log ($ inflation) & $\begin{array}{c}-0.187 * * * \\
{[0.036]}\end{array}$ & $\begin{array}{c}-0.137 * * * \\
{[0.041]}\end{array}$ & $\begin{array}{c}-0.164 * * * \\
{[0.037]}\end{array}$ & $\begin{array}{c}-0.166 * * * \\
{[0.038]}\end{array}$ & $\begin{array}{c}-0.181^{* * *} \\
{[0.035]}\end{array}$ & $\begin{array}{c}0.0133 \\
{[0.043]}\end{array}$ & $\begin{array}{c}-0.169 * * * \\
{[0.036]}\end{array}$ & $\begin{array}{c}-0.138 * * * \\
{[0.042]}\end{array}$ & $\begin{array}{c}-0.133^{* *} \\
{[0.056]}\end{array}$ & $\begin{array}{c}-0.0144 \\
{[0.051]}\end{array}$ \\
\hline log(telephone lines) & $\begin{array}{c}0.317^{* *} \\
{[0.13]}\end{array}$ & $\begin{array}{c}0.13 \\
{[0.12]}\end{array}$ & $\begin{array}{c}0.249^{* *} \\
{[0.11]}\end{array}$ & $\begin{array}{c}0.238^{* *} \\
{[0.11]}\end{array}$ & $\begin{array}{c}0.253^{* *} \\
{[0.11]}\end{array}$ & $\begin{array}{c}0.341^{* *} \\
{[0.16]}\end{array}$ & $\begin{array}{c}0.174 \\
{[0.12]}\end{array}$ & $\begin{array}{c}0.167 \\
{[0.12]}\end{array}$ & $\begin{array}{c}1.524 * * * \\
{[0.26]}\end{array}$ & $\begin{array}{c}0.124 \\
{[0.18]}\end{array}$ \\
\hline $\log$ (fuel) & $\begin{array}{c}0.0893 * * \\
{[0.037]}\end{array}$ & $\begin{array}{c}0.0849 * * \\
{[0.036]}\end{array}$ & $\begin{array}{c}0.0639 * \\
{[0.037]}\end{array}$ & $\begin{array}{c}0.0734^{* *} \\
{[0.037]}\end{array}$ & $\begin{array}{c}0.0439 \\
{[0.033]}\end{array}$ & $\begin{array}{c}-0.147 * * \\
{[0.063]}\end{array}$ & $\begin{array}{c}0.0509 \\
{[0.039]}\end{array}$ & $\begin{array}{c}0.0603 \\
{[0.038]}\end{array}$ & $\begin{array}{l}0.0179 \\
{[0.044]}\end{array}$ & $\begin{array}{c}0.102 \\
{[0.092]}\end{array}$ \\
\hline Qual. of Bureaucracy & $\begin{array}{c}0.151^{*} \\
{[0.081]}\end{array}$ & $\begin{array}{c}0.133 \\
{[0.082]}\end{array}$ & $\begin{array}{c}0.140 * \\
{[0.081]}\end{array}$ & $\begin{array}{l}0.178^{* *} \\
{[0.088]}\end{array}$ & $\begin{array}{c}0.207^{* * *} \\
{[0.080]}\end{array}$ & $\begin{array}{c}-0.440 * * * \\
{[0.13]}\end{array}$ & $\begin{array}{l}0.167 * * \\
{[0.082]}\end{array}$ & $\begin{array}{l}0.169^{* *} \\
{[0.082]}\end{array}$ & $\begin{array}{c}-0.0255 \\
{[0.12]}\end{array}$ & $\begin{array}{l}-0.106 \\
{[0.15]}\end{array}$ \\
\hline Executive constraints & $\begin{array}{l}0.110 * * \\
{[0.052]}\end{array}$ & $\begin{array}{c}0.112 * * \\
{[0.052]}\end{array}$ & $\begin{array}{c}0.0948 * \\
{[0.053]}\end{array}$ & $\begin{array}{c}0.101^{*} \\
{[0.053]}\end{array}$ & $\begin{array}{c}0.0661 \\
{[0.053]}\end{array}$ & $\begin{array}{c}0.168 * * * \\
{[0.058]}\end{array}$ & $\begin{array}{c}0.115 * * \\
{[0.052]}\end{array}$ & $\begin{array}{c}0.0923 * \\
{[0.053]}\end{array}$ & $\begin{array}{c}-0.173 * \\
{[0.10]}\end{array}$ & $\begin{array}{c}0.028 \\
{[0.065]}\end{array}$ \\
\hline Rule of Law & $\begin{array}{c}0.012 \\
{[0.044]}\end{array}$ & $\begin{array}{c}-0.00482 \\
{[0.043]}\end{array}$ & $\begin{array}{c}0.00198 \\
{[0.043]}\end{array}$ & $\begin{array}{l}-0.0163 \\
{[0.048]}\end{array}$ & $\begin{array}{c}-0.00574 \\
{[0.043]}\end{array}$ & $\begin{array}{c}-0.134^{*} \\
{[0.072]}\end{array}$ & $\begin{array}{l}-0.0293 \\
{[0.046]}\end{array}$ & $\begin{array}{l}-0.0115 \\
{[0.044]}\end{array}$ & $\begin{array}{c}0.320 * * * \\
{[0.068]}\end{array}$ & $\begin{array}{c}0.0377 \\
{[0.091]}\end{array}$ \\
\hline Overall fin. development & $\begin{array}{l}-0.672 \\
{[0.98]}\end{array}$ & $\begin{array}{c}-0.94 \\
{[0.97]}\end{array}$ & $\begin{array}{l}-1.009 \\
{[0.98]}\end{array}$ & $\begin{array}{l}-0.847 \\
{[0.98]}\end{array}$ & $\begin{array}{c}0.00603 \\
{[0.98]}\end{array}$ & $\begin{array}{c}-4.761^{* * *} \\
{[1.16]}\end{array}$ & $\begin{array}{l}-1.149 \\
{[0.98]}\end{array}$ & $\begin{array}{l}-1.077 \\
{[0.98]}\end{array}$ & $\begin{array}{c}0.82 \\
{[1.59]}\end{array}$ & $\begin{array}{c}-4.199 * * * \\
{[1.50]}\end{array}$ \\
\hline Trade liberalization & $\begin{array}{c}1.374 \\
{[1.70]}\end{array}$ & $\begin{array}{c}1.665 \\
{[1.71]}\end{array}$ & $\begin{array}{c}0.431 \\
{[1.77]}\end{array}$ & $\begin{array}{c}0.649 \\
{[1.82]}\end{array}$ & $\begin{array}{c}1.284 \\
{[1.68]}\end{array}$ & $\begin{array}{c}-3.293^{* *} \\
{[1.67]}\end{array}$ & $\begin{array}{c}1.17 \\
{[1.69]}\end{array}$ & $\begin{array}{l}0.782 \\
{[1.71]}\end{array}$ & $\begin{array}{l}5.182 \\
{[3.86]}\end{array}$ & $\begin{array}{c}-4.940 * * * \\
{[1.84]}\end{array}$ \\
\hline Privatization & $\begin{array}{c}1.010^{* * *} \\
{[0.38]}\end{array}$ & $\begin{array}{c}1.056^{* * *} \\
{[0.38]}\end{array}$ & $\begin{array}{c}1.067 * * * \\
{[0.38]}\end{array}$ & $\begin{array}{c}1.089 * * * \\
{[0.38]}\end{array}$ & $\begin{array}{c}1.004^{* * *} \\
{[0.38]}\end{array}$ & $\begin{array}{l}0.675^{*} \\
{[0.40]}\end{array}$ & $\begin{array}{c}1.099 * * * \\
{[0.38]}\end{array}$ & $\begin{array}{c}1.080^{* * *} \\
{[0.38]}\end{array}$ & $\begin{array}{c}1.671^{* * *} \\
{[0.54]}\end{array}$ & $\begin{array}{c}1.067 * * \\
{[0.47]}\end{array}$ \\
\hline competition & $\begin{array}{l}-0.0922 \\
{[0.074]}\end{array}$ & & & & & & & & & \\
\hline supervision & & $\begin{array}{l}0.150^{* *} \\
{[0.075]}\end{array}$ & & & & & & & & \\
\hline privatization_bank & & & $\begin{array}{c}0.0777 \\
{[0.053]}\end{array}$ & & & & & & & \\
\hline ccontrol & & & & $\begin{array}{c}0.0615 \\
{[0.074]}\end{array}$ & & & & & & \\
\hline capitalflows & & & & & $\begin{array}{c}-0.0741 \\
{[0.059]}\end{array}$ & & & & & \\
\hline creditceilings & & & & & & $\begin{array}{l}0.580 * \\
{[0.30]}\end{array}$ & & & & \\
\hline securitiesmarkets & & & & & & & $\begin{array}{c}0.152^{*} \\
{[0.079]}\end{array}$ & & & \\
\hline Financial liberalization index & & & & & & & & $\begin{array}{l}0.733^{*} \\
{[0.42]}\end{array}$ & $\begin{array}{l}-0.499 \\
{[0.66]}\end{array}$ & $\begin{array}{c}2.009 * * * \\
{[0.62]}\end{array}$ \\
\hline Observations & 245 & 245 & 245 & 245 & 253 & 113 & 245 & 245 & 145 & 100 \\
\hline Number of ccode & 24 & 24 & 24 & 24 & 25 & 13 & 24 & 24 & 11 & 13 \\
\hline Sargan test & 0.23 & 0.24 & 0.22 & 0.24 & 0.21 & 0.18 & 0.24 & 0.24 & 0.23 & 0.16 \\
\hline SOC & 0.3 & 0.25 & 0.29 & 0.27 & 0.22 & 0.26 & 0.27 & 0.28 & 0.5 & 0.33 \\
\hline
\end{tabular}

Regressions use the system-GMM estimator. All regressions include a constant term. Robust standard errors are reported in brackets. Instruments used are $\log (\mathrm{GDP}), \log$ (GDP per capita), $\log$ (inflation), $\log$ (telephone lines), $\log ($ fuel), quality of bureaucracy, executive constraints, rule of law, overall financial development, bank efficiency, trade liberalization, and privatization: for the difference equations, all in lagged levels and, for the level equation, in first difference. ${ }^{* * *}$, $^{* *}$, and $*$ denote significance at the $1 \%, 5 \%$, and $10 \%$ level, respectively. 
Table 3. Determinants of FDI: Nonfinancial vs. Financial FDI

[Dependent variable $=\log (\mathrm{FDI} / \mathrm{GDP})]$

\begin{tabular}{lcccccc}
\hline & NoFinFDI & FinFDI & NoFinFDI & FinFDI & NofinFDI & finFDI \\
& ALL & ALL & LAC & LAC & TE & TE \\
\hline $\log ($ GDP) & $-0.708^{* * *}$ & -0.0113 & $-1.766^{* * *}$ & $-1.385^{* * *}$ & $-0.766^{* *}$ & $-0.524^{* *}$ \\
& {$[0.18]$} & {$[0.19]$} & {$[0.26]$} & {$[0.30]$} & {$[0.33]$} & {$[0.24]$} \\
$\log$ (GDP per capita) & $0.572^{* * *}$ & 0.138 & $-0.728^{* *}$ & -0.275 & 0.0305 & $1.373^{* * *}$ \\
& {$[0.20]$} & {$[0.15]$} & {$[0.30]$} & {$[0.19]$} & {$[0.47]$} & {$[0.33]$} \\
$\log$ (inflation) & $-0.157^{* *}$ & $-0.126^{* *}$ & $-0.200^{* * *}$ & $-0.120^{*}$ & 0.0877 & 0.0271 \\
& {$[0.064]$} & {$[0.052]$} & {$[0.071]$} & {$[0.063]$} & {$[0.069]$} & {$[0.066]$} \\
$\log ($ telephone lines) & $0.504^{* * *}$ & -0.0721 & $2.043^{* * *}$ & $1.387^{* * *}$ & 0.164 & 0.233 \\
& {$[0.18]$} & {$[0.18]$} & {$[0.27]$} & {$[0.31]$} & {$[0.28]$} & {$[0.22]$} \\
$\log ($ fuel) & 0.0745 & 0.0236 & -0.101 & 0.0174 & 0.167 & 0.0243 \\
& {$[0.065]$} & {$[0.047]$} & {$[0.069]$} & {$[0.050]$} & {$[0.17]$} & {$[0.11]$} \\
Qual. of Bureaucracy & $0.285 *$ & 0.103 & 0.0566 & -0.0586 & 0.223 & $-0.350^{* *}$ \\
& {$[0.15]$} & {$[0.098]$} & {$[0.17]$} & {$[0.14]$} & {$[0.25]$} & {$[0.16]$} \\
Executive constraints & 0.0518 & $0.136^{*}$ & -0.0505 & -0.157 & -0.0782 & 0.138 \\
& {$[0.070]$} & {$[0.081]$} & {$[0.11]$} & {$[0.13]$} & {$[0.099]$} & {$[0.097]$} \\
Rule of Law & $-0.125^{*}$ & 0.0109 & $0.336^{* *}$ & $0.363^{* * *}$ & $0.312^{* *}$ & -0.0953 \\
& {$[0.065]$} & {$[0.053]$} & {$[0.13]$} & {$[0.076]$} & {$[0.15]$} & {$[0.10]$} \\
Financial liberalization index & -0.661 & $1.708^{* * *}$ & -1.039 & -0.389 & $6.598^{* * *}$ & $1.818^{* *}$ \\
& {$[0.81]$} & {$[0.54]$} & {$[1.10]$} & {$[0.81]$} & {$[1.47]$} & {$[0.72]$} \\
Overall fin. development & -1.259 & -0.935 & -1.786 & 2.188 & 1.01 & $-5.977^{* * *}$ \\
& {$[1.51]$} & {$[1.35]$} & {$[1.88]$} & {$[1.92]$} & {$[3.70]$} & {$[1.59]$} \\
Trade liberalization & -3.16 & 0.0378 & 2.866 & 5.14 & 0.751 & $-4.439^{* *}$ \\
& {$[3.06]$} & {$[2.00]$} & {$[7.97]$} & {$[4.59]$} & {$[2.78]$} & {$[2.04]$} \\
Privatization & $1.930^{* *}$ & $1.074^{* *}$ & $2.675^{* * *}$ & $1.199^{*}$ & $4.740^{* * *}$ & $0.865^{*}$ \\
Observations & {$[0.82]$} & {$[0.42]$} & {$[0.58]$} & {$[0.63]$} & {$[1.76]$} & {$[0.46]$} \\
Number of ccode & 72 & 173 & 36 & 109 & 36 & 64 \\
Sargan test & 17 & 22 & 8 & 11 & 9 & 11 \\
SOC & 0.27 & 0.5 & 0.16 & 0.27 & 0.08 & 0.15 \\
& 0.16 & 0.79 & 0.02 & 0.62 & 0.05 & 0.96 \\
& & & & & &
\end{tabular}

Regressions use the system-GMM estimator. All regressions include a constant term. Robust standard errors are reported in brackets. Instruments used are $\log (\mathrm{GDP}), \log$ (GDP per capita), $\log$ (inflation), $\log ($ telephone lines), $\log ($ fuel), quality of bureaucracy, executive constraints, rule of law, overall financial development, bank efficiency, trade liberalization, and privatization: for the difference equations, all in lagged levels and, for the level equation, in first difference. ${ }^{* * *},{ }^{* *}$, and $*$ denote significance at the $1 \%, 5 \%$, and $10 \%$ level, respectively. 
Table 4. Determinants of FDI: Robustness Check —Institutions

[Dependent variable $=\log (\mathrm{FDI} / \mathrm{GDP})]$

\begin{tabular}{|c|c|c|c|c|c|c|}
\hline & 1 & 2 & 3 & 4 & 5 & 6 \\
\hline $\log (\mathrm{GDP})$ & $\begin{array}{c}-0.398 * * * \\
{[0.093]}\end{array}$ & $\begin{array}{c}-0.394^{* * *} \\
{[0.094]}\end{array}$ & $\begin{array}{c}-0.324^{* * *} \\
{[0.10]}\end{array}$ & $\begin{array}{c}-0.502 * * * \\
{[0.088]}\end{array}$ & $\begin{array}{c}-0.539 * * * \\
{[0.099]}\end{array}$ & $\begin{array}{c}-0.523 * * * \\
{[0.099]}\end{array}$ \\
\hline log(GDP per capita) & $\begin{array}{c}0.214 * * \\
{[0.084]}\end{array}$ & $\begin{array}{c}0.268 * * * \\
{[0.077]}\end{array}$ & $\begin{array}{c}0.390 * * * \\
{[0.086]}\end{array}$ & $\begin{array}{c}0.464^{* * *} \\
{[0.074]}\end{array}$ & $\begin{array}{c}0.273^{* * *} \\
{[0.10]}\end{array}$ & $\begin{array}{c}0.427^{* * *} \\
{[0.089]}\end{array}$ \\
\hline $\log$ (inflation) & $\begin{array}{c}-0.151^{* * *} \\
{[0.037]}\end{array}$ & $\begin{array}{c}-0.136^{* * *} \\
{[0.037]}\end{array}$ & $\begin{array}{c}-0.122^{* * *} \\
{[0.041]}\end{array}$ & $\begin{array}{c}-0.134 * * * \\
{[0.037]}\end{array}$ & $\begin{array}{c}-0.140 * * * \\
{[0.036]}\end{array}$ & $\begin{array}{c}-0.144 * * * \\
{[0.039]}\end{array}$ \\
\hline log(telephone lines) & $\begin{array}{c}0.242^{* * *} \\
{[0.088]}\end{array}$ & $\begin{array}{c}0.296 * * * \\
{[0.087]}\end{array}$ & $\begin{array}{c}0.214^{* *} \\
{[0.097]}\end{array}$ & $\begin{array}{c}0.326 * * * \\
{[0.085]}\end{array}$ & $\begin{array}{c}0.336^{* * *} \\
{[0.089]}\end{array}$ & $\begin{array}{c}0.301^{* * *} \\
{[0.093]}\end{array}$ \\
\hline $\log$ (fuel) & $\begin{array}{c}0.0499 * \\
{[0.027]}\end{array}$ & $\begin{array}{c}0.0474 * \\
{[0.027]}\end{array}$ & $\begin{array}{c}0.0546 * \\
{[0.029]}\end{array}$ & $\begin{array}{c}0.0356 \\
{[0.025]}\end{array}$ & $\begin{array}{c}0.0408 \\
{[0.028]}\end{array}$ & $\begin{array}{c}0.0463 \\
{[0.031]}\end{array}$ \\
\hline Bank efficiency & $\begin{array}{c}2.703^{*} \\
{[1.41]}\end{array}$ & $\begin{array}{c}3.712^{* * *} \\
{[1.41]}\end{array}$ & $\begin{array}{c}5.676^{* * *} \\
{[1.59]}\end{array}$ & $\begin{array}{c}2.497 * * \\
{[1.22]}\end{array}$ & $\begin{array}{c}2.288^{*} \\
{[1.23]}\end{array}$ & $\begin{array}{c}3.146^{* *} \\
{[1.31]}\end{array}$ \\
\hline Trade liberalization & $\begin{array}{c}1.741 \\
{[1.48]}\end{array}$ & $\begin{array}{c}1.39 \\
{[1.48]}\end{array}$ & $\begin{array}{c}0.725 \\
{[1.61]}\end{array}$ & $\begin{array}{c}2.582 * * \\
{[1.09]}\end{array}$ & $\begin{array}{c}-0.3 \\
{[1.48]}\end{array}$ & $\begin{array}{c}-0.801 \\
{[1.48]}\end{array}$ \\
\hline Privatization & $\begin{array}{c}1.243^{* * *} \\
{[0.37]}\end{array}$ & $\begin{array}{c}1.254^{* * *} \\
{[0.37]}\end{array}$ & $\begin{array}{c}1.163^{* * * *} \\
{[0.39]}\end{array}$ & $\begin{array}{c}0.936 * * * \\
{[0.33]}\end{array}$ & $\begin{array}{c}1.354^{* * *} \\
{[0.37]}\end{array}$ & $\begin{array}{c}1.268 * * * \\
{[0.39]}\end{array}$ \\
\hline Qual. of Bureaucracy & $\begin{array}{c}0.225^{* * *} \\
{[0.069]}\end{array}$ & & & & & \\
\hline Executive constraints & & $\begin{array}{c}0.142^{* * *} \\
{[0.041]}\end{array}$ & & & & \\
\hline Rule of Law & & & $\begin{array}{c}0.0143 \\
{[0.044]}\end{array}$ & & & \\
\hline Corruption & & & & $\begin{array}{c}0.0345 \\
{[0.048]}\end{array}$ & & \\
\hline Political Risk & & & & & $\begin{array}{c}0.0127 \\
{[0.0083]}\end{array}$ & \\
\hline Durability & & & & & & $\begin{array}{c}0.00586^{* *} \\
{[0.0027]}\end{array}$ \\
\hline Observations & 298 & 298 & 298 & 314 & 244 & 244 \\
\hline Number of ccode & 31 & 31 & 31 & 35 & 30 & 30 \\
\hline Sargan test & 0.28 & 0.31 & 0.44 & 0.48 & 0.34 & 0.45 \\
\hline SOC & 0.16 & 0.19 & 0.2 & 0.78 & 0.29 & 0.32 \\
\hline
\end{tabular}

Regressions use the system-GMM estimator. All regressions include a constant term. Robust standard errors are reported in brackets. Instruments used are log(GDP), $\log$ (GDP per capita), log(inflation), $\log$ (telephone lines), $\log$ (fuel), quality of bureaucracy, executive constraints, rule of law, overall financial development, bank efficiency, trade liberalization, and privatization: for the difference equations, all in lagged levels and, for the level equation, in first difference. ***, **, and * denote significance at the $1 \%$, $5 \%$, and $10 \%$ level, respectively. 
Table 5. Determinants of FDI: Robustness Check — Infrastructure

[Dependent variable $=\log (\mathrm{FDI} / \mathrm{GDP})]$

\begin{tabular}{lcc}
\hline & ALL & ALL \\
\hline $\log ($ GDP) & $-0.323^{* * *}$ & $-0.338^{* * *}$ \\
& {$[0.068]$} & {$[0.060]$} \\
$\log$ (GDP per capita) & $0.353^{* * *}$ & $0.207^{* * *}$ \\
& {$[0.064]$} & {$[0.078]$} \\
$\log ($ inflation$)$ & $-0.114^{* * *}$ & $-0.109^{* * *}$ \\
& {$[0.024]$} & {$[0.026]$} \\
$\log ($ telephone lines) & $0.167^{* *}$ & \\
& {$[0.065]$} & \\
$\log$ (computer) & & $0.224^{* * *}$ \\
& & {$[0.050]$} \\
$\log ($ fuel) & $0.0778^{* * *}$ & $0.0566^{* *}$ \\
& {$[0.023]$} & {$[0.024]$} \\
Qual. of Bureaucracy & $0.141^{* * *}$ & $0.115^{* *}$ \\
& {$[0.046]$} & {$[0.053]$} \\
Executive constraints & $0.115^{* * *}$ & $0.166^{* * *}$ \\
Rule of Law & {$[0.029]$} & {$[0.045]$} \\
& 0.00222 & -0.00856 \\
Bank efficiency & {$[0.024]$} & {$[0.027]$} \\
Financial liberalization index & $1.997^{* *}$ & 1.242 \\
Trade liberalization & {$[0.84]$} & {$[0.88]$} \\
& $0.578^{* *}$ & $0.503^{*}$ \\
Privatization & {$[0.23]$} & {$[0.27]$} \\
& 1.032 & 0.625 \\
Observations & {$[0.94]$} & {$[0.97]$} \\
Number of ccode & $1.069^{* * *}$ & $1.208^{* * *}$ \\
Sargan test & {$[0.21]$} & {$[0.22]$} \\
SOC & 245 & 210 \\
\hline & 24 & 21 \\
& 0.22 & 0.23 \\
& 0.29 & 0.24 \\
\hline
\end{tabular}

Regressions use the system-GMM estimator. All regressions include a constant term. Robust standard errors are reported in brackets. Instruments used are $\log$ (GDP), $\log$ (GDP per capita), $\log ($ inflation), $\log ($ telephone lines), $\log ($ fuel), quality of bureaucracy, executive constraints, rule of law, overall financial development, bank efficiency, trade liberalization, and privatization: for the difference equations, all in lagged levels and, for the level equation, in first difference. ${ }^{* * *},{ }^{* *}$, and $*$ denote significance at the $1 \%, 5 \%$, and $10 \%$ level, 
Appendix 1. Summary Statistics

\begin{tabular}{lccccc}
\hline \multicolumn{1}{c}{ Variable } & Obs & Mean & Std.Dev. & Min & Max \\
\hline \hline & & & & & \\
$\log ($ FDI/GDP) & 582 & -4.73 & 1.12 & -8.3 & -2.2 \\
$\log ($ GDP) & 704 & 10.62 & 1.39 & 8.3 & 14.2 \\
$\log ($ GDP per worker) & 704 & 7.51 & 1.00 & 3.4 & 9.7 \\
$\operatorname{log(inflation)}$ & 563 & 2.70 & 1.65 & -3.0 & 8.9 \\
$\log ($ telephone) & 638 & 13.84 & 1.38 & 10.6 & 17.6 \\
$\log ($ fuel) & 523 & 1.39 & 1.94 & -4.6 & 4.5 \\
Executive constraints & 543 & 5.44 & 1.80 & 1 & 7 \\
Qual. of Bureaucracy & 498 & 1.93 & 0.86 & 0 & 4 \\
Rule of Law & 498 & 3.51 & 1.19 & 1 & 6 \\
Overall fin. development & 672 & 0.52 & 0.08 & 0 & 1 \\
Bank efficiency & 672 & 0.78 & 0.09 & 0 & 1 \\
Trade liberalization & 571 & 0.93 & 0.07 & 0 & 1 \\
Privatization & 704 & 0.05 & 0.11 & 0 & 1 \\
Financial liberalization Index & 473 & 0.58 & 0.23 & 0 & 1 \\
competition & 478 & 2.28 & 0.97 & 0 & 3 \\
supervision & 478 & 1.02 & 0.90 & 0 & 3 \\
privatization_banks & 478 & 1.23 & 1.18 & 0 & 3 \\
securitiesmarkets & 478 & 1.62 & 1.00 & 0 & 3 \\
creditceilings & 286 & 0.81 & 0.39 & 0 & 1 \\
capitalflows & 476 & 1.72 & 1.06 & 0 & 3 \\
creditcontrols & 474 & 1.87 & 1.00 & 0 & 3
\end{tabular}


Appendix 2. Data Descriotion and Sources

\begin{tabular}{|c|c|c|}
\hline Variable & Definition & Source \\
\hline 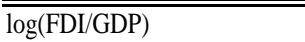 & Log of FDI to GDP ratio & WEO \\
\hline $\log (\mathrm{GDP})$ & Log of GDP & WEO \\
\hline log(GDP per worker) & Log of GDP per capita & WEO \\
\hline $\log ($ inflation) & Log of annual inflation & WEO \\
\hline $\log ($ telephone) & Log of number of main telephone lines & World Development Indicators \\
\hline $\log ($ computer) & Log of number of computers & World Development Indicators \\
\hline $\log ($ fuel $)$ & Log of fuel exports as \% of total exports & World Development Indicators \\
\hline Executive constraints & Executive constraints, operational de facto indepndence of chief executives & polity IV \\
\hline Qual. of Bureaucracy & $\begin{array}{l}\text { The extent to which the bureaucracy has the strength and expertise to govern without drastic changes in policy or } \\
\text { interruptions in government services. }\end{array}$ & ICRG \\
\hline Rule of Law & $\begin{array}{l}\text { Agreggate governance indicator measuring the quality of contract enforcement, the police, and the courts, as well as the } \\
\text { likelihood of crime and violence. }\end{array}$ & ICRG \\
\hline Overall fin. development & $\begin{array}{l}\text { Overall financial development index based on three underlying variables, the ratio of liquid liabilities to GDP, the ratio of } \\
\text { private sector credit to GDP, and the ratio of commercial bank assets to the total bank assets }\end{array}$ & Author's calculations \\
\hline Bank efficiency & Index of bank efficiency based on the ratio of overhead cost to total bank assets and net interest margin & Author's calculations \\
\hline Trade liberalization & Arithmetic average of normalized average tariff rate and tariff disperision & Author's calculations \\
\hline Privatization & Government's privatization proceeds & Kikeri and Kolo (2005) \\
\hline Corruption & Corruption indicator. Component of the political risk rating, counting for 6 of the 100 points. & ICRG \\
\hline Political risk & $\begin{array}{l}\text { Political risk rating measuring political stability using political and social attributes, from } 0 \text { (most risky) to } 100 \text { (least risky). } \\
\text { Composed of } 12 \text { weighed variables: government stability, socioeconomic conditions, investment profile, internal conflict, } \\
\text { external conflict, corruption, military in politics, religion in politics, law and order, ethnic tensions, democratic } \\
\text { accountability, and bureaucracy quality. }\end{array}$ & ICRG \\
\hline Durability & The number of years the dictator is in power & polity IV \\
\hline competition & $\begin{array}{l}\text { Policies to lower banking sector entry barriers: (i) foreign banks allowed to enter?, (ii) new domestic banks allowed to enter? } \\
\text { (iii) restrictions on branching?, (iv)allow banks to engage in a wide range of activities? }\end{array}$ & Detragiache and others, forthcoming \\
\hline supervision & $\begin{array}{l}\text { Policies to enhance banking sector supervision: (i) A country adopted capital adequacy ratio based on Basle standard, (ii) } \\
\text { banking supervisory agnecy indepndent from executive influence, (iii) does bankinhg supervisory agency conduct effective } \\
\text { supervisions? , (iv) does supervisory agency cover all financial institutions? }\end{array}$ & Detragiache and others, forthcoming \\
\hline privatization_bank & $\begin{array}{l}\text { Privatization of banks or the state involvement in the banking sector; }=3(\mathrm{FL}) \text { if no state banks exist, }=2(\mathrm{LL}) \text { if most banks are } \\
\text { privately owned, }=1(\mathrm{PR}) \text { if major banks are still state-owned, }=0(\mathrm{FR}) \text { if major banks arfe all state owned }\end{array}$ & Detragiache and others, forthcoming \\
\hline securitiesmarkets & $\begin{array}{l}\text { Policies to develop securities in stock markets: (i) a country took measures to develop securities markets, (ii) stock market } \\
\text { open to foreigners }\end{array}$ & Detragiache and others (2007) \\
\hline creditceilings & Ceilings on expansion of bank credit imposed by the $\mathrm{CB} ;=0$ if yes, $=1$ if no. & Detragiache and others (2007) \\
\hline capitalflows & Capital acocunt restrictions: (i) ex rate unified?, (ii) restrict capital inflow?, (iii) restrict capital outflows? & Detragiache and others (2007) \\
\hline Financial liberalization index & $\begin{array}{l}\text { A composite index of financial liberlization using bank entry, credit controls, securities markets, interest rates and bank } \\
\text { privatization }\end{array}$ & Detragiache and others (2007) \\
\hline
\end{tabular}


Appendix 3

Correlation matrix

fdi/gdp fdi/wk gdp_ppp gdp_pc inflation telephones fuel bureac $\sim y$ xconst ruleof w

$f d 1 b$

$\mathrm{fd} 2$

Tradelib privat

\begin{tabular}{|c|c|c|c|c|c|c|c|c|c|c|c|c|c|c|}
\hline fdi/gdp & $1.000 \odot$ & & & & & & & & & & & & & \\
\hline fdi/wk & 0.8048 & 1.0000 & & & & & & & & & & & & \\
\hline gdp_ppp_ & $-\odot . \odot 898$ & 0.0048 & 1.0000 & & & & & & & & & & & \\
\hline gdp_pc & 0.2622 & 0.5852 & 0.1506 & $1 . \odot \odot \odot \odot$ & & & & & & & & & & \\
\hline inflation & -0.1222 & -0.1001 & 0.1120 & -0.0681 & 1.0000 & & & & & & & & & \\
\hline telephone & -0.0801 & $-\odot .0 \odot 15$ & 0.9384 & $\odot .0771$ & 0.0279 & 1.0000 & & & & & & & & \\
\hline fuel & 0.0414 & -0.0599 & 0.1476 & -0.0765 & -0.0481 & 0.1922 & $1.000 \odot$ & & & & & & & \\
\hline bureacracy & 0.3672 & $\odot .5057$ & 0.1363 & 0.5564 & -0.0063 & 0.0467 & -0.1304 & 1.0000 & & & & & & \\
\hline$x$ const & 0.2952 & 0.2810 & -0.1871 & 0.2398 & -0.0803 & -0.2251 & -0.2160 & 0.4742 & 1.0000 & & & & & \\
\hline ruleoflaw & 0.2135 & 0.3965 & $-\odot .0713$ & 0.4059 & -0.0595 & -0.0639 & -0.1092 & 0.3920 & 0.2140 & $1.0 \odot \odot \odot$ & & & & \\
\hline fd $1 b$ & 0.1158 & 0.2134 & 0.0167 & 0.3136 & $-0.07 \odot 9$ & 0.0019 & -0.0194 & 0.2171 & -0.1247 & -0.0360 & 1.0000 & & & \\
\hline$f d 2$ & $\odot .1982$ & 0.2359 & -0.1302 & 0.2345 & -0.1051 & -0.0879 & -0.3942 & 0.1801 & 0.1294 & 0.0253 & 0.0713 & 1.0000 & & \\
\hline TradeLib & 0.1354 & 0.1154 & -0.1181 & 0.0299 & -0.0630 & -0.0927 & 0.0054 & -0.1275 & -0.0125 & -0.0991 & 0.0795 & $\Theta .1318$ & 1. $\odot \odot \odot \odot$ & \\
\hline privat & 0.2395 & 0.2334 & -0.0477 & 0.0976 & -0.0313 & -0.0534 & -0.0962 & 0.2060 & 0.1481 & 0.1269 & 0.0072 & 0.1454 & -0.0048 & 1.0000 \\
\hline
\end{tabular}




\section{DAVIDSON INSTITUTE WORKING PAPER SERIES - Most Recent Papers}

The entire Working Paper Series may be downloaded free of charge at: www.wdi.umich.edu

CURRENT AS OF 2/6/08

\begin{tabular}{|c|c|c|}
\hline Publication & Authors & Date \\
\hline $\begin{array}{l}\text { No. 906: Foreign Direct Investment and Structural Reforms: } \\
\text { Evidence from Eastern Europe and Latin America }\end{array}$ & Nauro Campos \& Yuko Kinoshita & Jan 2008 \\
\hline $\begin{array}{l}\text { No. 905: From Workers to Owners: Survey Evidence on the Impact of } \\
\text { Property Rights Reforms on Small Farmers in Two Regions in Romania }\end{array}$ & $\begin{array}{l}\text { Georgeta Vidican-Sgouridis and } \\
\text { Annette Kim }\end{array}$ & Jan 2008 \\
\hline $\begin{array}{l}\text { No. 904: Are Emerging Economies Fdi Inflows Cointegrated With Fdi } \\
\text { Inflows Of China? - An Empirical Investigation }\end{array}$ & $\begin{array}{l}\text { Krishna Chaitanya, Vadlamannati } \\
\text { \& Emilia Vazquez Rozas }\end{array}$ & Dec 2007 \\
\hline $\begin{array}{l}\text { No. 903: Some New Insights into Currency Boards: } \\
\text { Evidence from Bulgaria }\end{array}$ & $\begin{array}{l}\text { Alexandru Minea and Christophe } \\
\text { Rault }\end{array}$ & Jan 2008 \\
\hline $\begin{array}{l}\text { No. 902: Should we care for structural breaks when assessing fiscal } \\
\text { sustainability? }\end{array}$ & $\begin{array}{l}\text { António Afonso and Christophe } \\
\text { Rault }\end{array}$ & Nov 2007 \\
\hline $\begin{array}{l}\text { No. 901: A Forewarning Indicator System For Financial Crises : The } \\
\text { Case Of Six Central And Eastern European Countries }\end{array}$ & $\begin{array}{l}\text { Irène Andreou, Gilles Dufrénot, } \\
\text { Alain Sand-Zantman, and } \\
\text { Aleksandra Zdzienicka-Durand }\end{array}$ & May 2007 \\
\hline No. 900: Directional Mobility of Debt Ratings & $\begin{array}{l}\text { Sumon Kumar Bhaumik and John } \\
\text { S. Landon-Lane }\end{array}$ & Nov 2007 \\
\hline $\begin{array}{l}\text { No. 899: The Choice of Exchange Rate Regimes in the MENA Countries: } \\
\text { a Probit Analysis }\end{array}$ & Sfia M. Daly & Oct 2007 \\
\hline $\begin{array}{l}\text { No. 898: Macroeconomic Sources of Foreign Exchange Risk } \\
\text { in New EU Members }\end{array}$ & $\begin{array}{l}\text { Evzen Kocenda and Tirgran } \\
\text { Poghosyan }\end{array}$ & Oct 2007 \\
\hline $\begin{array}{l}\text { No. 897: Rapid Economic Growth And Industrialization } \\
\text { In India, China \& Brazil: At What Cost? }\end{array}$ & Krishna Chaitanya.V & Oct 2007 \\
\hline $\begin{array}{l}\text { No. 896: Factors influencing corporate governance in post-socialist } \\
\text { companies: an analytical framework }\end{array}$ & $\begin{array}{l}\text { Andreas Heinrich, Aleksandra } \\
\text { Lis and Heiko Pleines }\end{array}$ & Oct 2007 \\
\hline $\begin{array}{l}\text { No. 895: Real Convergence, Price Level Convergence and } \\
\text { Inflation Differentials in Europe }\end{array}$ & Balázs Égert & Oct 2007 \\
\hline $\begin{array}{l}\text { No. 894: Determinants of House Prices in Central and Eastern } \\
\text { Europe }\end{array}$ & $\begin{array}{l}\text { Balázs Égert and Dubravko } \\
\text { Mihaljek }\end{array}$ & Oct 2007 \\
\hline $\begin{array}{l}\text { No. 893: What Do We Really Know About Fiscal Sustainability in the } \\
\text { EU? A Panel Data Diagnostic }\end{array}$ & $\begin{array}{l}\text { António Afonso and Christophe } \\
\text { Rault }\end{array}$ & Oct 2007 \\
\hline $\begin{array}{l}\text { No. 892: The Political Economy of Corruption and the Role of Financial } \\
\text { Institutions }\end{array}$ & Kira Boerner and Christa Hainz & Oct 2007 \\
\hline $\begin{array}{l}\text { No. 891: Growth, Volatility and Political Instability: Non-Linear time } \\
\text { Series Evidence for Argentina 1896-2000 }\end{array}$ & $\begin{array}{l}\text { Nauro Campos and Menelaos } \\
\text { Karanasos }\end{array}$ & Sept 2007 \\
\hline No. 890: Social Costs of Mass Privatization & $\begin{array}{l}\text { David Stuckler and Lawrence } \\
\text { King }\end{array}$ & Sept 2007 \\
\hline $\begin{array}{l}\text { No. 889: A Rise By Any Other Name? Sensitivity of Growth Regressions } \\
\text { to Data Source }\end{array}$ & $\begin{array}{l}\text { Randall Filer, Dana Hajkova and } \\
\text { Jan Hanousek }\end{array}$ & July 2007 \\
\hline No. 888: Mind the Gap! Social Capital, East and West & Jan Fidrmuc and Klarita Gerxhani & June 2007 \\
\hline No. 887: Ever Closer Union or Babylon Discord? & $\begin{array}{l}\text { Jan Fidrmuc, Victor Ginsburgh } \\
\text { and Schlomo Weber }\end{array}$ & July 2007 \\
\hline $\begin{array}{l}\text { No. 886: FDI \& the Consequences towards more complete capture of } \\
\text { spillover effects }\end{array}$ & $\begin{array}{l}\text { Bruno Merlevede and Koen } \\
\text { Schoors }\end{array}$ & Aug 2007 \\
\hline No. 885: Consumption Smoothing and Vulnerability in Russia & $\begin{array}{l}\text { Christopher J. Gerry and Carmen } \\
\text { A. Li }\end{array}$ & July 2007 \\
\hline No. 884: National Cultural \& Financial Systems & $\begin{array}{l}\text { Solomon Tadesse and Chuck } \\
\text { Kwok }\end{array}$ & $\begin{array}{l}\text { March } \\
2005\end{array}$ \\
\hline $\begin{array}{l}\text { No. 883: Stock Markets Liquidity, Corporate Governance and Small } \\
\text { Firms }\end{array}$ & Solomon Tadesse & June 2005 \\
\hline $\begin{array}{l}\text { No. 882: The MNC as an Agent of Change for Host-Country Institutions: } \\
\text { FDI \& Corruption }\end{array}$ & $\begin{array}{l}\text { Chuck Kwok and Solomon } \\
\text { Tadesse }\end{array}$ & Sept 2006 \\
\hline
\end{tabular}

